\title{
New Notharctine (Primates, Adapiformes) Skull From the Uintan (Middle Eocene) of San Diego County, California
}

\author{
GREGG F. GUNNELL \\ Museum of Paleontology, University of Michigan, Ann Arbor, Michigan \\ 48109-1079
}

\begin{abstract}
KEY WORDS Californian primates, Cranial morphology, Haplorhine-strepsirhine dichotomy
\end{abstract}

\begin{abstract}
A new genus and species of notharctine primate, Hesperolemur actius, is described from Uintan (middle Eocene) aged rocks of San Diego County, California. Hesperolemur differs from all previously described adapiforms in having the anterior third of the ectotympanic anulus fused to the internal lateral wall of the auditory bulla. In this feature Hesperolemur superficially resembles extant cheirogaleids. Hesperolemur also differs from previously known adapiforms in lacking bony canals that transmit the internal carotid artery through the tympanic cavity. Hesperolemur, like the later occurring North American cercamoniine Mahgarita stevensi, appears to have lacked a stapedial artery. Evidence from newly discovered skulls of Notharctus and Smilodectes, along with Hesperolemur, Mahgarita, and Adapis, indicates that the tympanic arterial circulatory pattern of these adapiforms is characterized by stapedial arteries that are smaller than promontory arteries, a feature shared with extant tarsiers and anthropoids and one of the characteristics often used to support the existence of a haplorhine-strepsirhine dichotomy among extant primates. The existence of such a dichotomy among Eocene primates is not supported by any compelling evidence. Hesperolemur is the latest occurring notharctine primate known from North America and is the only notharctine represented among a relatively diverse primate fauna from southern California. The coastal lowlands of southern California presumably served as a refuge area for primates during the middle and later Eocene as climates deteriorated in the continental interior. Hesperolemur probably was an immigrant taxon that entered California from either the northern (Wyoming/Utah) or southern (New Mexico) western interior during the middle Eocene 1995 Wiley-Liss, Inc.
\end{abstract}

Terrestrial fossil mammals from the Eocene Sespe Formation of southern California were first described in a series of papers by Stock (1932, 1933a-d, 1934a-d, 1935a-d, $1936 \mathrm{a}-\mathrm{c}$ ) and Wilson (1935). Shortly afterward, mammals were described from Eocene rocks in the greater San Diego area (Stock 1937, 1938; Wilson, 1940a-c). Golz (1976), Golz and Lillegraven (1977), Lillegraven (1976), Kelly (1990), Mason (1990), Kelly et al. (1991), and Walsh (1991) have provided more recent reviews of Eocene terrestrial mammals from southern California.

The San Diego Natural History Museum has been conducting fieldwork in the greater San Diego area for the past several years (Walsh, 1991). During the course of this

Received September 26, 1994; accepted June 21, 1995

Address reprint requests to Gregg F. Gunnell, Museum of Paleontology, University of Michigan, Ann Arbor, MI 48109-1079. 
fieldwork, a primate skull was discovered from rocks of early Uintan age. The purpose of this paper is to describe the new primate, to compare it with other notharctid and adapid primates from North America and Europe, and to provide a summary of primate faunas from San Diego and Ventura counties.

Institutional abbreviations and designations used in the text are as follows: AMNH, American Museum of Natural History, New York, NY; BMNH, Natural History Museum, London, United Kingdom; CM, Carnegie Museum of Natural History, Pittsburgh, PA; Halle, Geiseltal Museum, Halle, Germany; Louis, Private collection of P. Louis, Cormicy, France; MNHN, Muséum National d'Histoire Naturelle, Paris, France; MPM, Milwaukee Public Museum, Milwaukee, WI; NHB, Basel, Naturhistorisches Museum, Basel, Switzerland; PLV, Laboratorium voor Actuopaleontologie, Katholieke Universiteit, Louvain, Belgium; SDSNH, San Diego Society of Natural History, San Diego, CA; TMM, Texas Memorial Museum, Austin, TX; UALP, University of Arizona, Laboratory of Paleontology, Tucson, AZ; UCMP, University of California, Museum of Paleontology, Berkeley, CA; UL, University of Lyon, Lyon, France; UM, University of Michigan, Museum of Paleontology, Ann Arbor, MI; USGS, United States Geological Survey, Denver, CO; USNM, United States National Museum, Washington, DC; YPM, Yale Peabody Museum, New Haven, CT.

\section{MATERIALS AND METHODS Measurements and nomenclature}

All tooth measurements were taken with dial calipers under a binocular microscope and recorded to the nearest tenth millimeter. Length $(L)$ measurements record maximum mesiodistal tooth dimensions, and width (W) measurements record maximum buccolingual breadth. Upper teeth are designated by tooth position with superscripts and lower teeth by subscripts with $\mathrm{I}=$ incisor, $\mathrm{C}=$ canine, $\mathrm{P}=$ premolar, and $\mathrm{M}=$ molar. All measurements of arterial canal widths were made using a binocular microscope with an optical micrometer at $\times 10$. Arterial pathways referred to as canals are those surrounded by bone and manifest as a hollow tube, while those that are not enclosed in bone are referred to as grooves.

\section{Comparative samples}

Comparisons of the new California primate were made with a wide range of adapiforms, either with original specimens or high quality casts. Included in these comparisons were the following: European adapiforms: Adapis parisiensis (UM 63301, 63302, Cambridge M.538, Montauban-4); Agerinia roselli (Unnumbered holotype and Cecilie 4241); Anchomomys gaillardi (UL L-46bis); Anchomomys stehlini (Basel En-1); Caenopithecus lemuroides (NHB Eh 597-728); Cantius eppsi (BMNH 13773, 15145, 15147, 29639); Cantius savagei (Louis Collection Mu 155-158, 160, MNHN Av 4846, 5907, 7702, Gr 98); Cercamonius brachyrhynchus (Basel Qv 619);Donrussellia gallica (MNHN Av many unnumbered teeth); Donrussellia louisi (MNHN Av 4731, 4845, 5664 and unnumbered teeth from Avenay and Grauves); Europolemur klatti (Halle--unnumbered dentary from Geiseltal and Halle 4238, 4292, 4304, 7325, 7396); Leptadapis magnus (Basel Qv 545, 920, MNHN Qu 10943); Periconodon (= Anchomomys?) pygmaeus (Basel En 367, Halle 7418, MNHN Bchs 494); Pronycticebus gaudryi (MNHN unnumbered holotype skull, Qu 11057); Protoadapis curvicuspidens (AL 5182, 5719); Protoadapis filholi (PLV 35); Protoadapis russelli (MNHN Av 4644, 5759); Protoadapis sp. (MNHN Gr 150 and unnumbered teeth from Bouxwiller); North American adapiforms: Cantius abditus (many specimens in UM collections, AMNH 4734); Cantius angulatus (AMNH $55505,55510,55515$ ); Cantius frugivorus (AMNH 16210, 55501, 86296, CM 37448); Cantius mckennai (many specimens in UM collections); Cantius ralstoni (many specimens in UM collections); Cantius torresi (many specimens in UM collections); Copelemur australotutus (USNM 22261, 411833); Copelemur praetutus (USNM 411882, 411886, YPM 14698); Copelemur tutus (AMNH 16205, 55462, UALP 11377-8); Mahgarita stevensi (TMM 41578-9); Notharctus robinsoni (many specimens in UM collections); Notharctus tenebrosus (many specimens in UM collections); Pelycodus jarrovii (CM 37453, USGS 6549); Smilodectes graci- 
lis (USNM 17994, 21815, YPM 12904, many specimens in UM collections); Smilodectes mcgrewi (many specimens in UM collections). Comparisons were also made with the plesiadapiform taxa Plesiadapis cookei (UM 87990) and Ignacius graybullianus (UM 68006).

\section{RESULTS}

\section{Systematic paleontology}

Order Primates Linnaeus, 1758

Suborder Prosimii Illiger, 1811

Infraorder Adapiformes Szalay and Delson, 1979

Family Notharctidae Trouessart, 1879

Subfamily Notharctinae Trouessart, 1879

\section{Hesperolemur, gen. nov.}

Notharctus (Lillegraven, 1980).

Type species. Hesperolemur actius, sp. nov.

Diagnosis. Hesperolemur differs from all other known adapiforms in lacking canals enclosing the internal carotid arterial system within the tympanic cavity and in having the anterior third of the ectotympanic and the anterior crus fused to the internal surface of the lateral wall of the auditory bulla; it differs from adapids (Adapis and Leptadapis) in having a smaller sagittal crest, in having less massive zygomatics, in having a premolariform $\mathrm{P}^{4}$, and in having upper molars with a protocone fold (= "pseudohypocone") and a well-developed metaconule; it differs from cercamoniines (European notharctids and North American Mahgarita) in having upper molars with a protocone fold and well-developed metaconule and lower third molars with basally inflated, very robust protoconids and metaconids and a flexed cristid obliqua; differs from North American notharctines Cantius, Notharctus, Copelemur, and Pelycodus in lacking lower molar paraconids; it differs from Smilodectes and Copelemur in having closed lower molar trigonids and inflated protoconid and metaconid cusps.
Etymology. Latin, hesperus, west, and lemur, ghost of the departed.

Discussion. Franzen (1987) has proposed resurrecting Trouessart's (1879) family Notharctidae to include all adapiforms except Adapis, Leptadapis, and Cryptadapis, which remain in the family Adapidae. This arrangement accounts for the divergent characteristics of Adapis, Leptadapis, and Cryptadapis while recognizing the fundamental similarities of other adapiforms. Most North American notharctids are placed in the subfamily Notharctinae, differentiated from European notharctids (Cercamoniinae) mainly by the presence of protocone folds, metaconules, and mesostyles on upper molars. The lone North American exception is Mahgarita, which is placed within cercamoniines based on the presence of a cingular ("true") hypocone and an absence of metaconules and mesostyles on upper molars.

While Hesperolemur is generically distinct from other North American notharctines, it clearly shares common ancestry with the taxa in this subfamily (Cantius, Pelycodus, Copelemur, Notharctus, and Smilodectes). Like these taxa, Hesperolemur has upper molars with protocone folds and strong metaconules, both characteristics that stand in contrast to cercamoniines and adapids. Cranially, Hesperolemur is similar to Notharctus in most features, differing substantially only in the disposition of the tympanic cavity.

\section{Hesperolemur actius, sp. nov.}

Notharctus sp. near $N$. robustior (Lillegraven, 1980).

Holotype. SDSNH 35233, compressed skull with left and right $\mathrm{P}^{4}-\mathrm{M}^{3}$, collected by R.A. Cerutti, December 7, 1987, from SDSNH locality 3413, Azuaga II, site 5 .

Referred specimens. SDSNH 42415, right $\mathrm{M}_{3}$, from SDSNH locality 3380 , Carmel Mountain Ranch, Unit 16, site 3; UCMP 113256, broken left $\mathrm{M}_{2}$ from UCMP locality V-72157.

Horizon. The type and referred specimens were collected from early Uintan (middle Eocene) strata originally mapped as Mission Valley Formation by Kennedy and Moore (1975) and regarded as a new litho- 
stratigraphic unit by Walsh (1991). These strata are now tentatively correlated by Walsh (personal communication) with the type Friars Formation.

Diagnosis. As for genus.

Etymology. Latin, aktios, coastal, referring to the coastal setting of the San Diego localities.

Description. SDSNH 35233 is a dorsoventrally compressed and somewhat plastically deformed skull of a relatively large notharctine primate (Fig. 1). The anterior portion of the skull is missing in front of $\mathrm{P}^{4}$. The skull now measures $70.2 \mathrm{~mm}$ in length and $48.2 \mathrm{~mm}$ in maximum width but obviously would have been both longer and wider had it not been crushed and broken. No sutures are evident anywhere on the skull because of crushing and step-fracturing of cranial elements.

Lateral view (Fig. 1A). Only a few features of Hesperolemur can be discerned in lateral view due to crushing and breakage. The maxillary, from the base of the orbit to the gingival margin, is relatively narrow dorsoventrally, more so than in other North American notharctines. It is much narrower than in Adapis. The infraorbital foramina are relatively larger than in Notharctus, Smilodectes, Cantius (UM 93938), and Adapis and are positioned above $\mathrm{P}^{4}$ as in those taxa. The root of the jugal originates dorsal to the posterior root of $\mathrm{M}^{1}$, making it more anteriorly placed than in Notharctus, Smilodectes, or Adapis but about as in Cantius.

The orbits are crushed, but, judging from relatively undistorted portions of the orbital margin, they would have been about the relative size of those in North American notharctines, relatively larger than those exhibited in Adapis. The lacrimal canal appears to have been positioned just inside the orbit as in Notharctus, Smilodectes, and Adapis, where it interrupts the continuity of the anterior orbital margin. This condition differs from Cantius (UM 93938 (Fig. 2), where the lacrimal canal is positioned anterior to the orbital margin such that the anterior orbital rim forms a continuous, unbroken border. The morphology of the orbital fossa in Hesperolemur is completely obscured by broken and overlapping bone fragments.
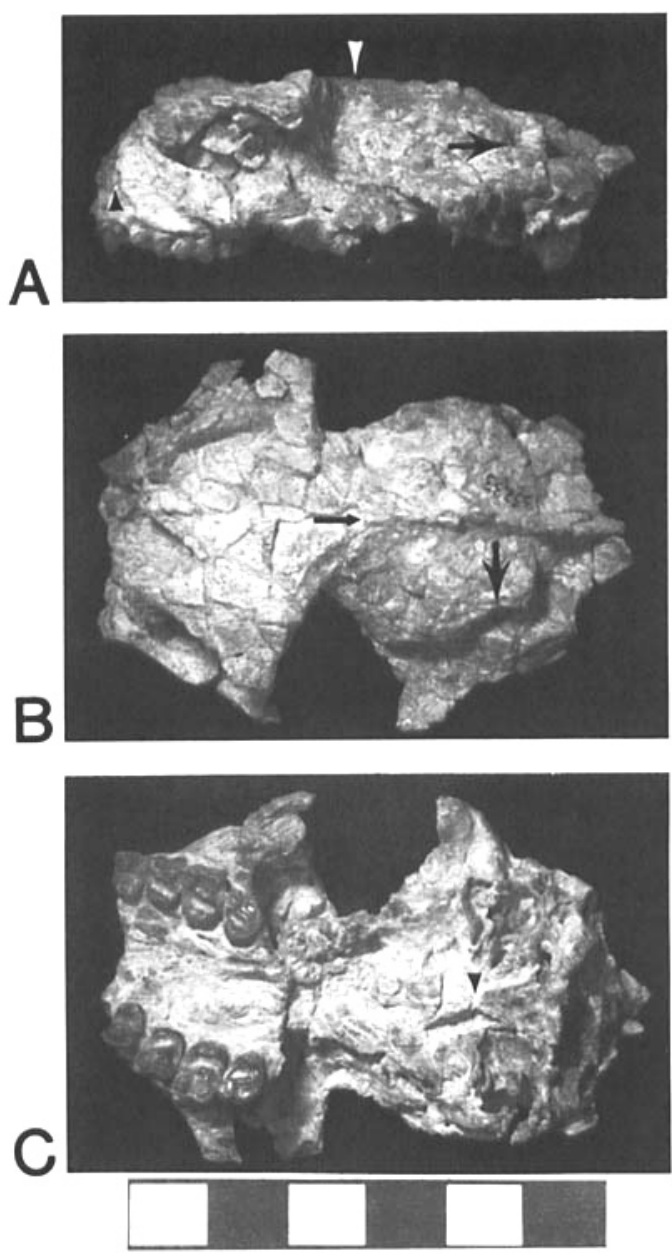

Fig. 1. Skull of Hesperolemur actius (SDSNH 35233 , holotype). A: Lateral view. Small black triangle to left indicates position of infraorbital foramen, white arrowhead indicates position of confluence of frontal lines, and black arrow indicates position of parietosquamosal foramen. B: Dorsal view. Small black arrow to left indicates position of confluence of frontal lines; larger arrow to right indicates position of parietosquamosal foramen. C: Ventral view. Small black triangle indicates position of basisphenoid-basioccipital suture. Anterior to left in all views. Scale in $1 \mathrm{~cm}$ increments.

Dorsal view (Fig. 1B). The skull exhibits relatively strong postorbital constriction dividing it into distinct splanchnocranium and neurocranium. The nasals are not preserved. The frontals are relatively broad as in Smilodectes (Gazin, 1958) and Notharctus (Gregory, 1920) but unlike Adapis, in which the frontals are constricted and concave 


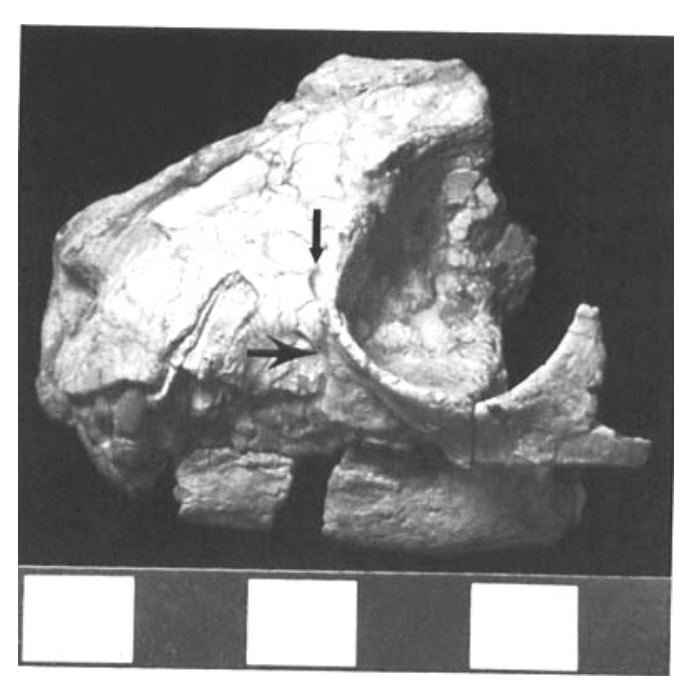

Fig. 2. Rostrum of Cantius abditus (UM 93938) in lateral view, anterior to left. Small black arrow above indicates position of the lacrimal canal; larger arrow below indicates position of infraorbital foramen. Scale in $1 \mathrm{~cm}$ increments.

(Stehlin, 1912; Gingerich, 1981a; Gingerich and Martin, 1981). There is no evidence to suggest that the frontals were inflated as in Smilodectes (Gazin, 1958), but instead they were probably flattened as in Notharctus. The frontals taper laterally to form relatively broad superior rami of the postorbital bars, very similar to the condition exhibited in Smilodectes. The frontal lines converge at the midline just posterior to the postorbital constriction much as in Adapis and unlike Smilodectes or Notharctus, where the frontal lines join farther posteriorly.

Hesperolemur has a well-developed sagittal crest extending from the confluence of the frontal lines posteriorly to the nuchal crest. The sagittal crest is less developed than is typical of Adapis (Gingerich, 1981a) but is better developed than it is in most specimens of Smilodectes (which almost never has a sagittal crest) or Notharctus (where a weak to moderate sagittal crest often is present). The braincase is pearshaped, being relatively broad and rounded posteriorly, tapering anteriorly to the postorbital constriction. The anterior biparietal width $(20.9 \mathrm{~mm})$ is comparable to that of Smilodectes gracilis $(21.0 \mathrm{~mm})$ but much broader than it is in Adapis parisiensis (11.3 $\mathrm{mm}$ ). The braincase is not inflated anteriorly as it is in Smilodectes but tapers more gradually to the postorbital constriction.

The anterior, posterior, and ventral extent of the parietals is obscured by crushing. Hesperolemur appears to have distinct parietosquamosal foramina as in Smilodectes, Notharctus, and Adapis, but they are positioned more anteriorly than in those taxa. If interpreted correctly, these foramina are located more dorsally than in Smilodectes or Notharctus, which suggests that the dorsolateral portion of the squamosal was relatively more extensive than in either of these taxa, more like the condition exhibited in Adapis. The root of the zygomatic arch in Hesperolemur is relatively broad anteroposteriorly as in Notharctus and Smilodectes. Although broken, it does not appear to have extended posteriorly to form dẻep temporal gutters as in Adapis (Stehlin, 1912).

Ventral view (Fig. 1C). The skull of Hesperolemur preserves the left and right maxillary tooth rows $\left(\mathrm{P}^{4}\right.$ to $\left.\mathrm{M}^{3}\right)$, small portions of the basisphenoid, crushed and plastically deformed petrosals, and a somewhat distorted basioccipital. The anterior portions of the basisphenoid are missing. Posteriorly, the basisphenoid contacts the basioccipital at about the anteriormost point of the auditory bullae as in Notharctus and Smilodectes, relatively more posteriorly than in Adapis. The basisphenoid contacts the anteromedial portion of the bullae anterior to its contact with the basioccipital as in $\mathrm{No}$ tharctus. The basisphenoid does not appear to overlap the bullae as in Smilodectes. The central ridge of the basisphenoid is broad and relatively flat as in Notharctus, not narrower and more elevated as in Adapis or laterally compressed and sharply defined as in Smilodectes. The mesopterygoid fossa appears to have been only moderately excavated laterally as in Adapis and Notharctus, not deeply pocketed as in Smilodectes (Gazin, 1958).

The basioccipital of Hesperolemur is narrow anteriorly and widens posteriorly, forming a relatively broad surface approaching the condition in Notharctus but not as broad as in Adapis and not as laterally impinged upon by the bullae as in Smilodectes. The 
basioccipital does not overlap the medial wall of the auditory bullae as it does in Notharctus and especially Smilodectes but does contact it more broadly than in Adapis. The basioccipital has a relatively weak median ridge extending from its anterior contact with the basisphenoid to the margin of the foramen magnum much as in Notharctus but unlike Adapis, where this ridge appears to be absent, or Smilodectes, where a median ridge is well developed.

The auditory bullae are relatively large, continuous with the petrosal, and rounded anteromedially. These taper slightly posterolaterally but do not form an ossified external auditory meatus. The anteromedial extent of the petrosal reaches beyond the contact of the basisphenoid and basioccipital as in Notharctus, but this is not as anteriorly extended as in Adapis. Anteriorly, the bullae overlap the posterior margins of the basisphenoids, unlike Smilodectes, where the basisphenoids overlap the bullae.

Tympanic cavity. Morphological features of the tympanic cavity can be discerned from both the left and right side of the skull of Hesperolemur. The right tympanic cavity has been crushed anteriorly, tilting all of the preserved features anterodorsally to posteroventrally (Fig. 3A). The left tympanic cavity has been crushed dorsoventrally and anteriorly, pushing most of the middle ear dorsally (Figs. 3B, 4). Even with such distortion, many of the relevant features of middle ear morphology are preserved on one side or the other.

The tympanic cavity of Hesperolemur is separable into four distinct regions. There is a relatively large anteromedial cavity ( $\mathrm{Si}$ mons and Rasmussen, 1989; Rasmussen, 1990) roofed by the epitympanic wing of the petrosal. This cavity is divided into anterior and posterior areas by a medial secondary septum (MacPhee, 1981). A relatively large anterolateral cavity is present, roofed by the "tegmen tympani." Posterolaterally, the tympanic cavity is mediodorsally limited by the facial canal and laterally by a deep epitympanic recess. The posteromedial portion of the tympanic cavity is occupied by the promontorium and associated structures.

Although crushed and broken, many of the features of the tympanic roof of Hespero- lemur can be discerned by examining both left and right ear regions (Fig. 3C). The promontorium (best seen in the right ear region [Fig. 3A]) is a rounded eminence. At the dorsal base of the posterior portion of the promontorium is the cochlear fenestra, somewhat hidden by a posterior extension of the promontorium. Just lateral to the cochlear fenestra is a small fossa that may represent the point of origin for the stapedius muscle. The vestibular fenestra (best seen in the left ear region [Figs. 3B, 4]) is located along the lateral margin of the promontorium. The epitympanic recess is lateral to the vestibular fenestra. The tensor tympani fossa is located just anterior to the epitympanic recess.

Relatively large stylomastoid foramina are preserved on both left and right bullae located posterolaterally. It is possible to follow the course of the facial canal through the stylomastoid foramen and into the tympanic cavity. However, the course of the facial canal cannot be traced farther due to breakage. It presumably crossed the tympanic cavity at the medial margin of the epitympanic recess as in other notharctines, but this is impossible to determine with certainty.

The circulatory pattern of the internal carotid arterial system in Hesperolemur appears quite different from that documented for all previously known notharctines (Gregory, 1920; Szalay, 1975; Szalay and Delson, 1979). Like other notharctines, the internal carotid artery presumably entered the bulla posteriorly, ventral and medial to the stylomastoid foramen (neither ear region preserves the posterior carotid foramen). Unlike other known adapiforms (and other Eocene primates), there is no evidence of any bony canals enclosing arteries within the tympanic cavity (Figs. 3A,B, 4). It is difficult to determine the exact path of the internal carotid artery until it reaches the promontorium. There is a large, deep groove (not a canal) along the lateral aspect of the promontorium that represents the promontorial pathway of the promontory artery, but no tube or canal is present that is continuous with this groove either anteriorly or posteriorly. Some specimens of Smilodectes and Notharctus have canals that are open across the lateral part of the promontorium (manifest as a groove), but well-developed, closed 

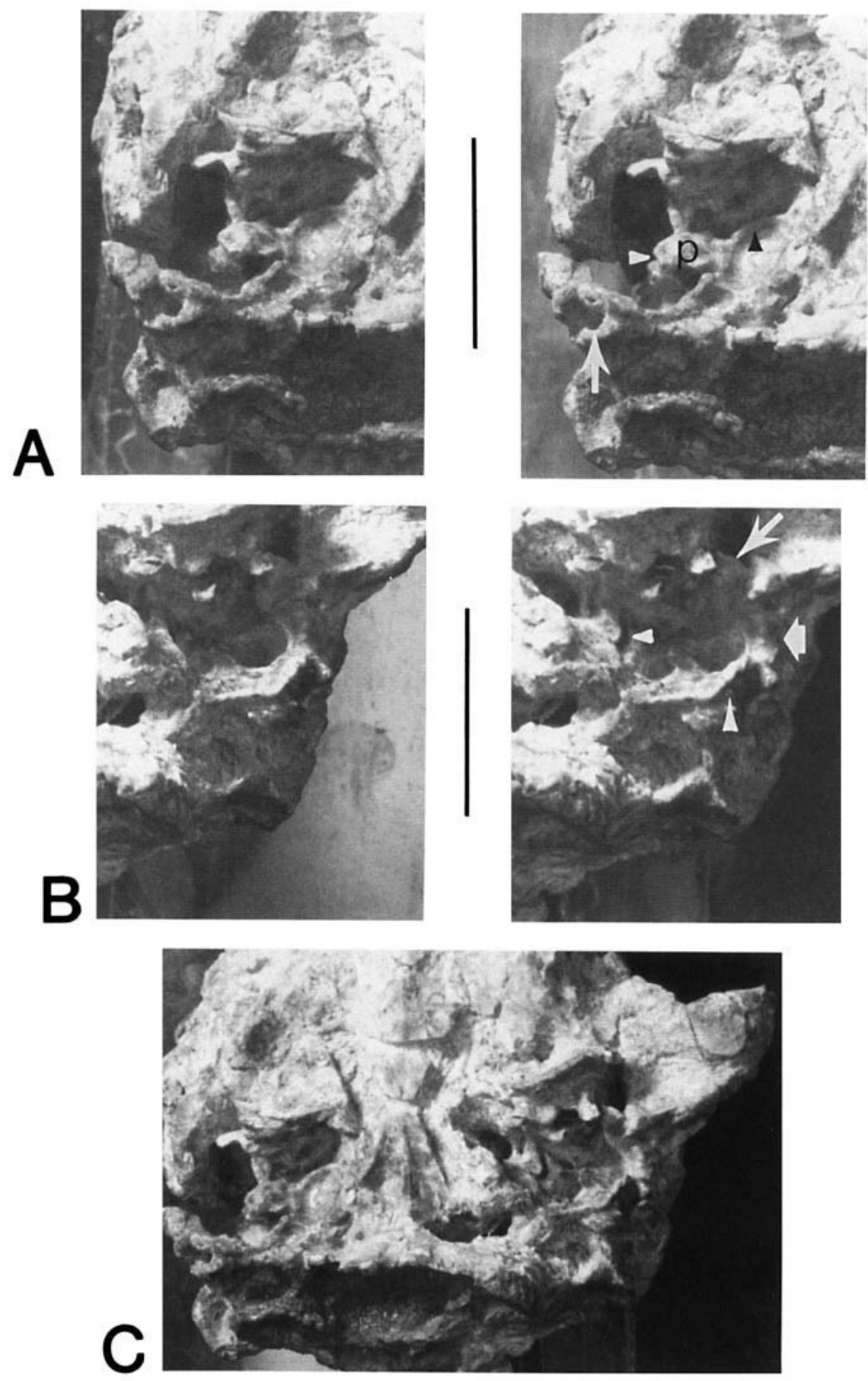

Fig. 3. Stereophotographs of tympanic regions of Hesperolemur actius (SDSNH 35233, holotype). A: Ventral view of right tympanic cavity with anterior to top and lateral to left showing promontorium (p), stylomastoid foramen (white arrow), groove across lateral surface of promontorium for promontory artery (white arrowhead), and medial secondary septum (black arrowhead). B: Ventral view of left tympanic cavity with anterior to top and lateral to right showing stylomastoid foramen (white arrowhead at bottom right), groove across lateral surface of the promontorium for the promontory artery (white arrowhead to left), anterior portion of the ectotympanic anulus (white arrow at top), and the position of the auditory meatus (large white arrow to right). $\mathbf{C}$ : Photograph of entire basicranial region of $H$. actius, anterior to top. Scale $=1 \mathrm{~cm}$. 

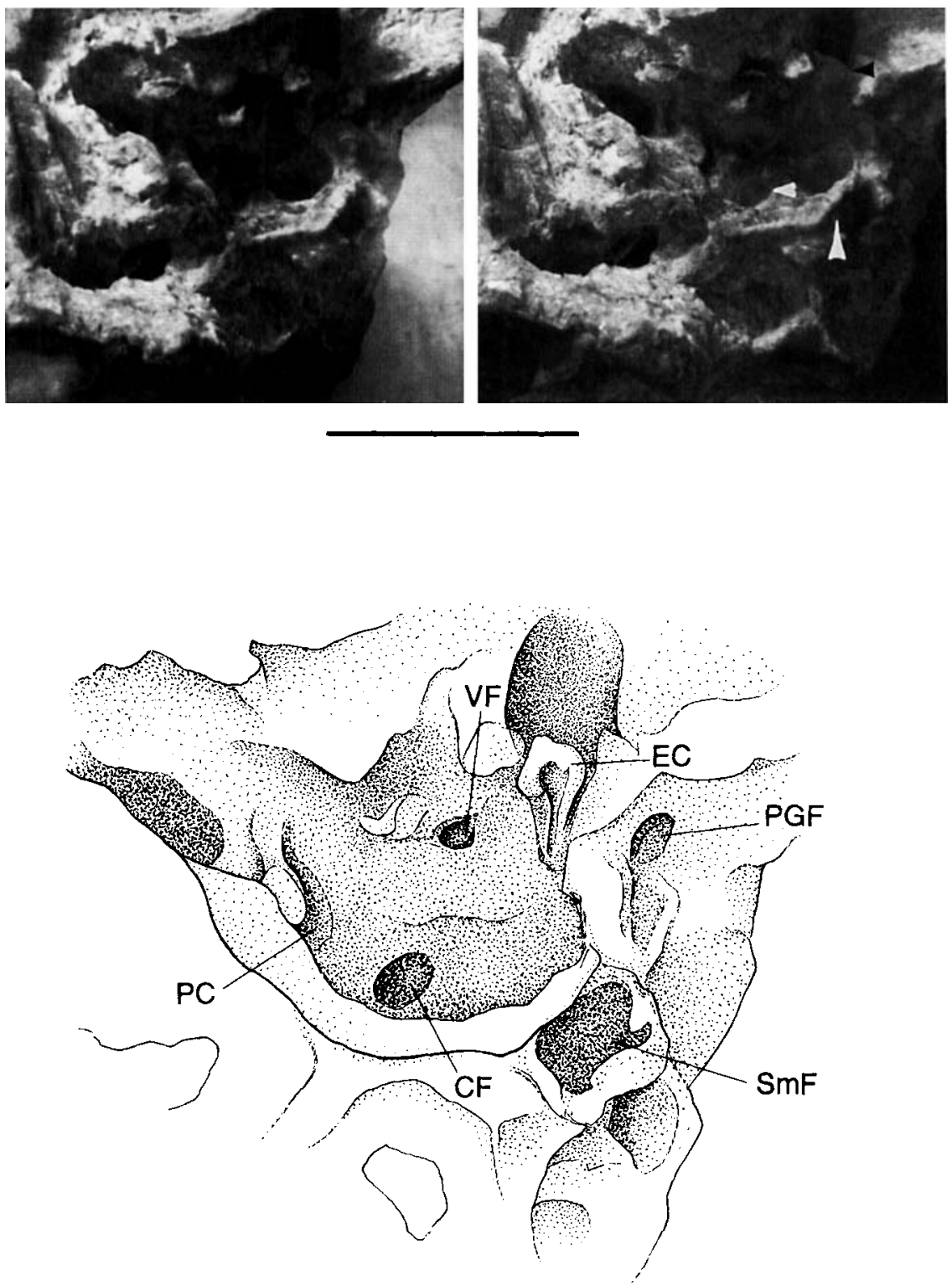

Fig. 4. Stereophotographs of left ear region of Hesperolemur actius (SDSNH 35233, holotype) and line drawing indicating relevant features, anterior to top and lateral to right. On photographs, white arrowhead at bottom indicates the stylomastoid foramen, white arrowhead to left indicates cochlear fenestra, and black arrowhead at top indicates anterior portion of ectotympanic

canals are present throughout the rest of the internal carotid circulatory pathway through the tympanic cavity. It is possible that these canals are simply missing in Hesperolemur because of breakage, but the anulus. CF, cochlear fenestra: EC, ectotympanic; PC, groove for promontory branch of internal carotid artery; PGF, postglenoid foramen; SmF, stylomastoid foramen; VF, vestibular fenestra. Photographic scale $=1 \mathrm{~cm}$. Stylomastoid foramen appears deceptively large in drawing due to breakage and oblique position.

areas where such canals would have connected are smooth and show no signs of any bony portions having been broken off. In addition, there were no broken bone fragments within the tympanic cavities that could be 
TABLE 1. Promontory and stapedial canal diameters in notharctines

\begin{tabular}{llccc}
\hline Specimen & \multicolumn{1}{c}{ Genus/species } & Promontory (narrowest) & Stapedial (broadest) & Aspect \\
\hline UM 98828 & Notharctus tenebrosus & $1.0 \mathrm{~mm}$ & $0.50 \mathrm{~mm}$ & External \\
UM 98828 & Notharctus tenebrosus & - & $0.40 \mathrm{~mm}$ & Internal \\
YPM 11466 & Notharctus tenebrosus & $0.60 \mathrm{~mm}$ & $0.40 \mathrm{~mm}$ & Internal \\
UM 100000 & Smilodectes gracilis & $1.0 \mathrm{~mm}$ & $0.50 \mathrm{~mm}$ & Internal \\
UM 100044 & Smilodectes gracilis & $1.3 \mathrm{~mm}$ & $0.80 \mathrm{~mm}$ & External \\
UM 100521 & Smilodectes gracilis & $1.7 \mathrm{~mm}$ & $0.80 \mathrm{~mm}$ & External \\
UM 101212 & Smilodectes gracilis & $1.3 \mathrm{~mm}$ & $0.80 \mathrm{~mm}$ & External \\
UM 100603 & Smilodectes mcgrewi & $1.2 \mathrm{~mm}$ & - & External \\
SDSNH 35233 & Hesperolemur actius & $0.9 \mathrm{~mm}$ & Internal \\
\hline
\end{tabular}

${ }^{1}$ From Gingerich (1973).

${ }^{2}$ Measured at bifurcation of internal carotid artery.

attributed to these canals, which seems unlikely given that other delicate structures (ear ossicles, portions of the ectotympanic anulus) were found within the tympanic cavities.

Hesperolemur also differs from known notharctids in apparently lacking a canal or groove for the stapedial artery. It is difficult to be certain of this because of the condition of the ear regions, but there is no evidence apparent for the existence of a stapedial artery (Figs. 3A,B, 4). The lack of a stapedial artery in Hesperolemur seems incongruous with previous notions of the disposition of arterial circulation through the middle ear in "extinct strepsirhines" (Szalay, 1975; Szalay and Delson, 1979). It has been suggested that the strepsirhine condition is one in which the stapedial artery is larger than the promontory artery, while the opposite holds in haplorhines (Gregory, 1920; Szalay, 1975; Szalay and Delson, 1979; but also see MacPhee and Cartmill, 1986; Ross, 1994). There has been some evidence to suggest that the supposed strepsirhine condition is not representative of notharctines (Gingerich, 1973; MacPhee and Cartmill, 1986), Adapis (Gingerich and Martin, 1981), or Mahgarita (Rasmussen, 1990), but this evidence has been disputed (Wilson and Szalay, 1976; Szalay and Delson, 1979).

Gingerich (1973) provided measurements of diameters of bony canals in one specimen of Notharctus (YPM 11466) that indicated that the promontory artery was, in fact, larger than the stapedial artery (see Table 1). Gingerich and Martin (1981) provided measurements of the Cambridge skull of $A d$ apis where the same condition holds. MacPhee and Cartmill (1986) note that two skulls of Smilodectes (MPM 2612 and 5409) both have promontory canals much (their italics) larger than stapedial canals. Fieldwork in the Bridger Formation of southwestern Wyoming has produced six additional notharctine skulls (UM numbers 98828 (Notharctus tenebrosus), 100000, 100044, 100521, 101212 (Smilodectes gracilis), and 100603 (Smilodectes mcgrewi) (Figs. 5, 6) that provide additional support for the morphology cited by Gingerich (1973) and MacPhee and Cartmill (1986). In all cases, by either external or internal diameters, the promontory canal is larger than the stapedial canal in these notharctine specimens. While this does not necessarily prove that the arteries in these canals reflected the same relationship, it does call into question the usefulness of such a character for recognition of a haplorhine-strepsirhine dichotomy among middle Eocene primates. If relative size of promontory and stapedial arteries is a valid character differentiating strepsirhines from haplorhines (this is in dispute, see Beard and MacPhee, 1994), then adapiforms are haplorhines, a conclusion few proponents of Strepsirhini-Haplorhini would support (although see Cartmill and Kay, 1978). Other lines of evidence do not support the existence of a strepsirhinehaplorhine dichotomy among Eocene primates (Simpson, 1940; Gingerich, 1981b; Rasmussen, 1986, 1990, 1994; Beard, 1988; Cartmill, 1994). The reality is that such a dichotomy simply is not usefully applied to the early primate radiation. In any event, the relatively large size of the promontory arterial groove and the apparent lack of a stapedial artery in Hesperolemur is not out 

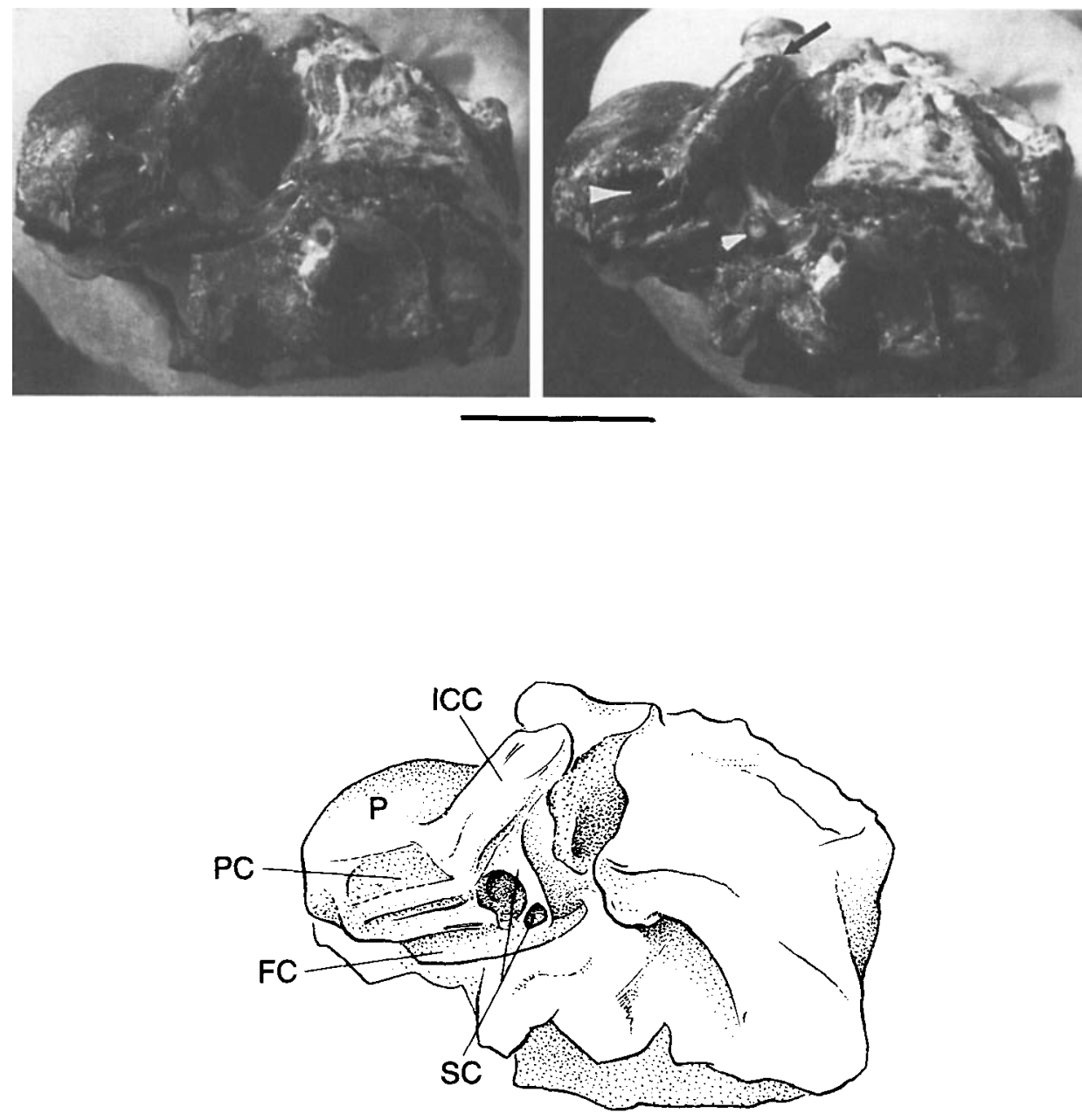

Fig. 5. Stereophotographs of right middle ear region of Notharctus tenebrosus (UM 98828) and line drawing indicating relevant features, ventral to top and anterior to left. On photographs, white arrowhead to left indicates the promontory canal on the lateral aspect of the promontorium with canal partially opened to show caliber; smaller white arrowhead to right indicates opening of stapedial canal as it crosses the facial canal (below); black arrow at top indicates internal carotid canal. FC, facial canal; ICC, internal carotid canal; P, promontorium; PC, promontory canal (with bone removed laterally to show caliber of opening); SC, stapedial canal. Photographic scale $=4 \mathrm{~mm}$.

along the anterodorsal margin of the auditory meatus. It is attached to the bullar wall by a solid, bony anular bridge (MacPhee and Cartmill, 1986; MacPhee, 1987). There is a small suture or crack running along the lateral margin of the ectotympanic suggesting the presence of a recessus dehiscence (MacPhee, 1987) and indicating that the anular bridge is petrosal in origin. A grooved surface that served as the attachment area for the tympanic membrane is formed by a wall just medial to the postglenoid foramen 

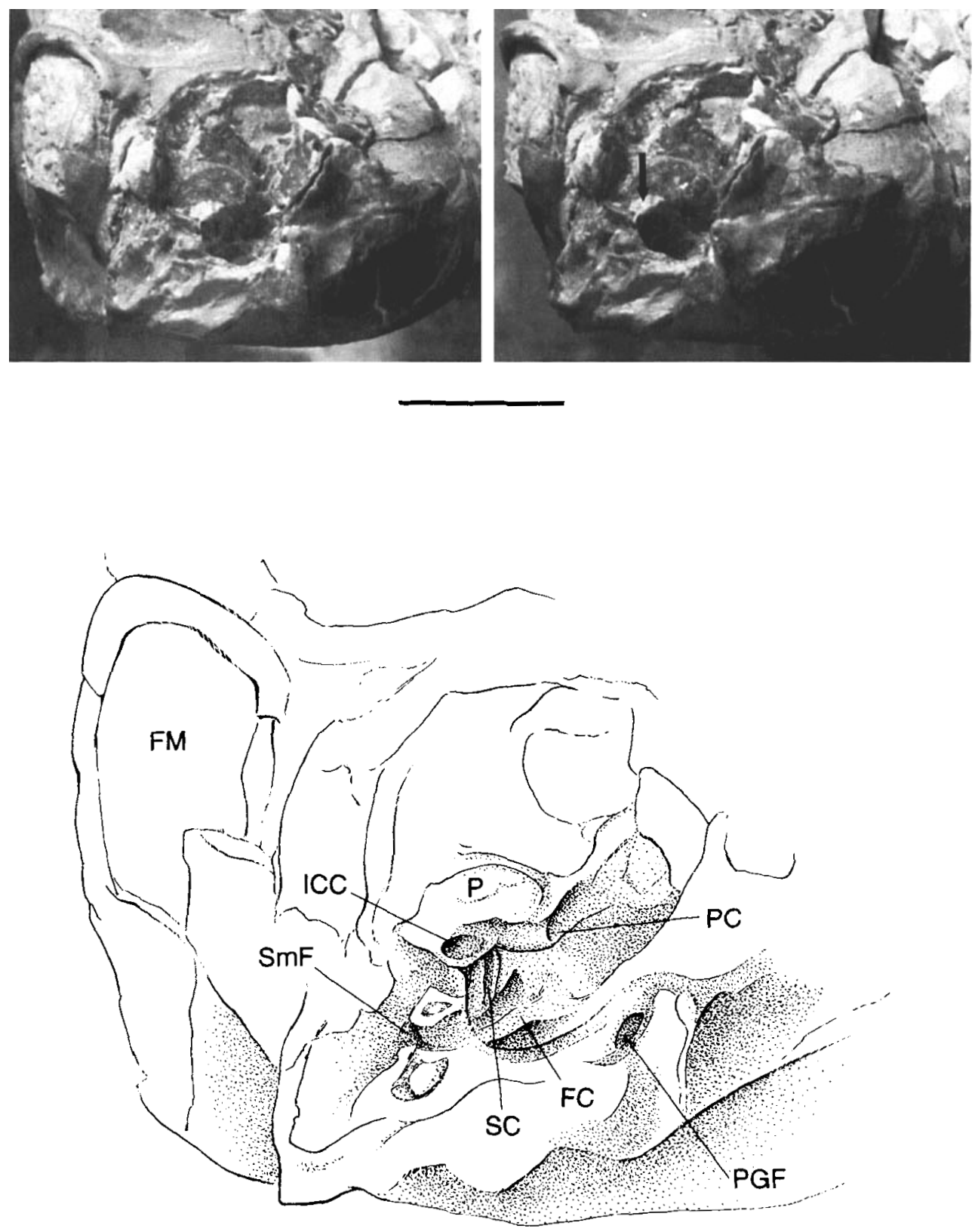

Fig. 6. Stereophotographs of left ear region of Smilodectes gracilis (UM 100000) and line drawing indicating relevant features, anterior to right and ventral to top. Black arrow on photograph indicates position and opening of internal carotid artery. FC, facial canal; FM, foramen magnum; ICC, internal carotid artery; P, promont-

strong ridge (crista tympani) located along the medial margin of the ectotympanic fragment.

Unlike Smilodectes (MacPhee and Cart- orium; PC, promontory canal (with bone removed anteriorly to show caliber of opening); PGF, postglenoid foramen; SC, stapedial canal (with bone removed laterally to show caliber of opening); $\mathrm{SmF}$, stylomastoid foramen. Photographic scale $=1 \mathrm{~cm}$.

mill, 1986), the anterior portion of the ectotympanic of Hesperolemur is fused to the lateral bullar wall throughout its course. UM 100521 and 101212 (Fig. 7) show the 

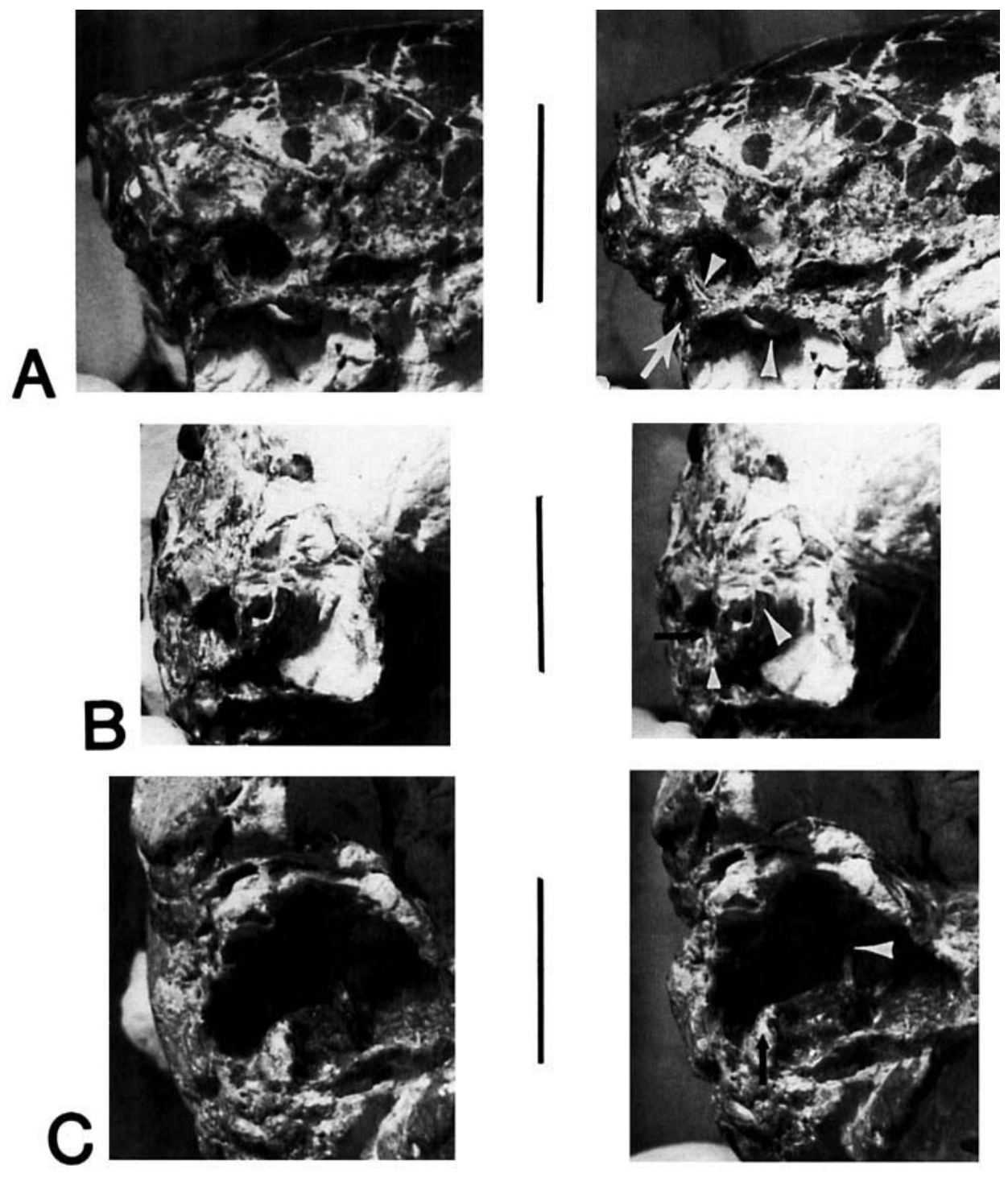

Fig. 7. Stereophotographs of right ear region of Smilodectes gracilis showing disposition of ectotympanic. A: UM 100521 in lateral view with anterior to right and dorsal to top. Small white arrowheads indicate posterior crus (left) and broken "free" segment (right) of ectotympanic; white arrow at lower left indicates position of the internal carotid foramen. B: UM 100521 in ventrolateral view with anterior to top and lateral to left. Small white arrowhead indicates posterior crus of ectotympanic

fused to anular bridge, larger white arrowhead indicates broken "free" segment of ectotympanic, and black arrow indicates anterior crus located along dorsal surface of the auditory meatus. C: UM 101212 in ventral view with anterior to top and lateral to left. Black arrow indicates position of internal carotid foramen; white arrowhead indicates broken "free" portion of ectotympanic lying anteromedial to promontorium. Scale $=1 \mathrm{~cm}$.

disposition of the ectotympanic in Smilodectes gracilis. The posterior crus of Smilodectes is connected to the lateral bullar wall via an anular bridge. After the ectotympanic passes the level of the internal carotid canal,

it is no longer attached to the bulla, exhibiting the "free" ring condition of extant Lemur (anular bridge incomplete sensu MacPhee and Cartmill, 1986). The ectotympanic anulus may contact a small portion 
of the lateral bullar wall along its anterior curvature as in Lemur but is not fused to the lateral wall anteriorly as in Hesperolemur. The anterior crus of Smilodectes rests in the auditory meatal fossa (the crus is clearly visible in UM 100521 [Fig. 7B]). The anterior crus of the ectotympanic of Hesperolemur does not appear to lie in a meatal fossa but is instead attached to the internal surface of the lateral bullar wall at the auditory meatus similar to extant Otolemur.

The presence or absence of a continuous bony connection between the ectotympanic and the lateral bullar wall (a complete anular bridge [see MacPhee and Cartmill, 1986; MacPhee, 1987; Beard and MacPhee, 1994]) cannot be determined. If Hesperolemur was like other known notharctids it would have lacked a complete anular bridge (MacPhee and Cartmill, 1986; MacPhee, 1987; Franzen, 1987). However, the fact that the anterior third of the ectotympanic is solidly attached to the lateral bullar wall via an anular bridge suggests that the entire ectotympanic may have been similarly connected to the bulla. There is a small piece of bullar wall from the ventrolateral portion of the right bulla of Hesperolemur that has a smooth, shallow groove running anteroposteriorly across its dorsal surface. This may represent a band or groove for the ectotympanic and if so suggests that the ectotympanic was in close proximity to the dorsal bullar surface, but there is no evidence to indicate that the ectotympanic was directly connected to the bulla in this area. If Hesperolemur had an ectotympanic anulus attached to the dorsal surface of the bulla throughout its course by a complete or nearly complete anular bridge, it would have resembled the condition exhibited by some extant cheirogaleids (Cartmill, 1975; MacPhee and Cartmill, 1986).

The malleus fragment of Hesperolemur is represented only by the incudal articular surface and provides little information about the complete disposition of this ossicle. Compared to Smilodectes gracilis (UM 101212), the malleus of $H$. actius is somewhat smaller, and the incudal articular surface is flatter and less saddle-shaped.

The right incus of Hesperolemur is nearly complete, missing only the long crus, while the left incus is missing both the long and short crura. Comparisons with a left incus of Smilodectes gracilis (UM 100000) indicate that Hesperolemur and Smilodectes shared most features of incudal morphology (Fig. $8 \mathrm{~A}, \mathrm{~B})$. The body of the incus in both taxa has distinct medial and lateral mallear facets that are oriented at nearly 90 degrees to one another. The medial mallear facet is more concave than the lateral facet, especially in Smilodectes, although the lateral facet is somewhat saddle-shaped in both taxa. The short crus is relatively shorter and less robust in Hesperolemur, and, although the long crus is missing, judging by the angle of the broken surface, it must have been more inferiorly oriented than in Smilodectes, resulting in the short and long crura being relatively farther apart in Hesperolemur.

Other characteristics of the basicranium are also evident on the skull of Hesperolemur. The mastoid region, while not relatively large, did enclose at least two substantial air cells. The mastoids are not as inflated as in Adapis but approach the condition exhibited in Smilodectes and Notharctus. The glenoid fossa is relatively wider mediolaterally than in Smilodectes but is approached by Adapis in this characteristic. The postglenoid process is robust and angled slightly posteriorly as in Smilodectes. It may have contacted the bulla, unlike Smilodectes, but does not appear to have been fused to the bulla anterior to the external auditory meatus as in Adapis. There is a distinct postglenoid foramen located on the posteromedial aspect of the postglenoid process abutting against the anterior portion of the auditory meatus.

Dentition. The skull of Hesperolemur preserves $\mathrm{P}^{4}-\mathrm{M}^{3}$ on both sides (Figs. 1C, 9B). $\mathrm{P}^{4}$ is a mesiodistally compressed tooth with a well-developed protocone that is positioned near the mesiolingual base of the paracone. The paracone is nearly twice the height of the protocone. The paracone is centrally placed along the buccal margin producing a preparacrista and postparacrista of nearly equal length. There is no metacone. $\mathrm{P}^{4}$ has a small parastyle and no metastyle. There is a weak cingulum that encircles the tooth.

The molars are quite worn across the lingual half of their occlusal surfaces. $\mathbf{M}^{2}$ is 

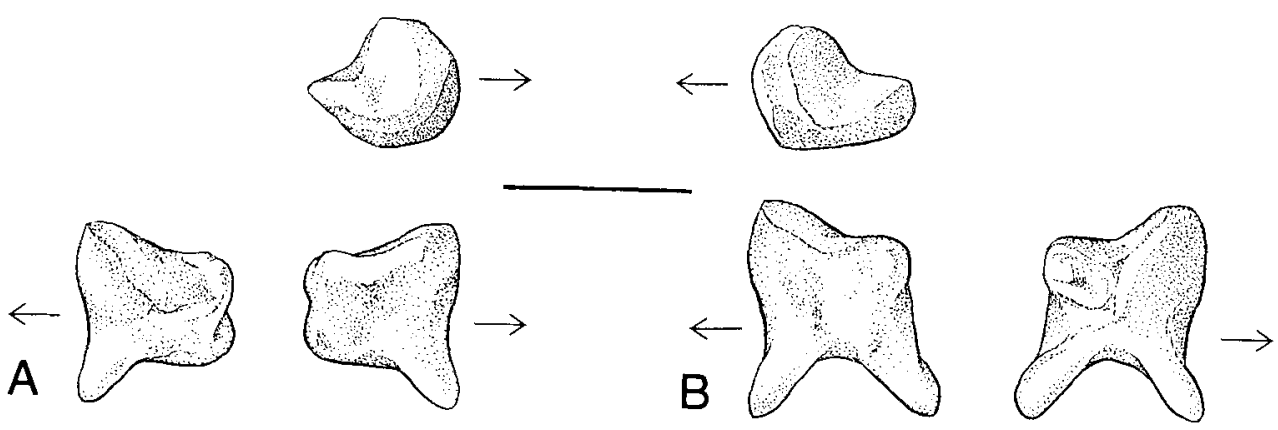

Fig. 8. Line drawings of (A) right incus of Hesperolemur actius (SDSNH 35233, holotype) and (B) left incus of Smilodectes gracilis (UM 100000). In A, lateral view is bottom left, medial view is bottom right, and anterior view is top. In $\mathrm{B}$, medial view is bottom left, lateral view is bottom right, and anterior view is top. Small arrows point dorsally in each view. Scale $=2 \mathrm{~mm}$.
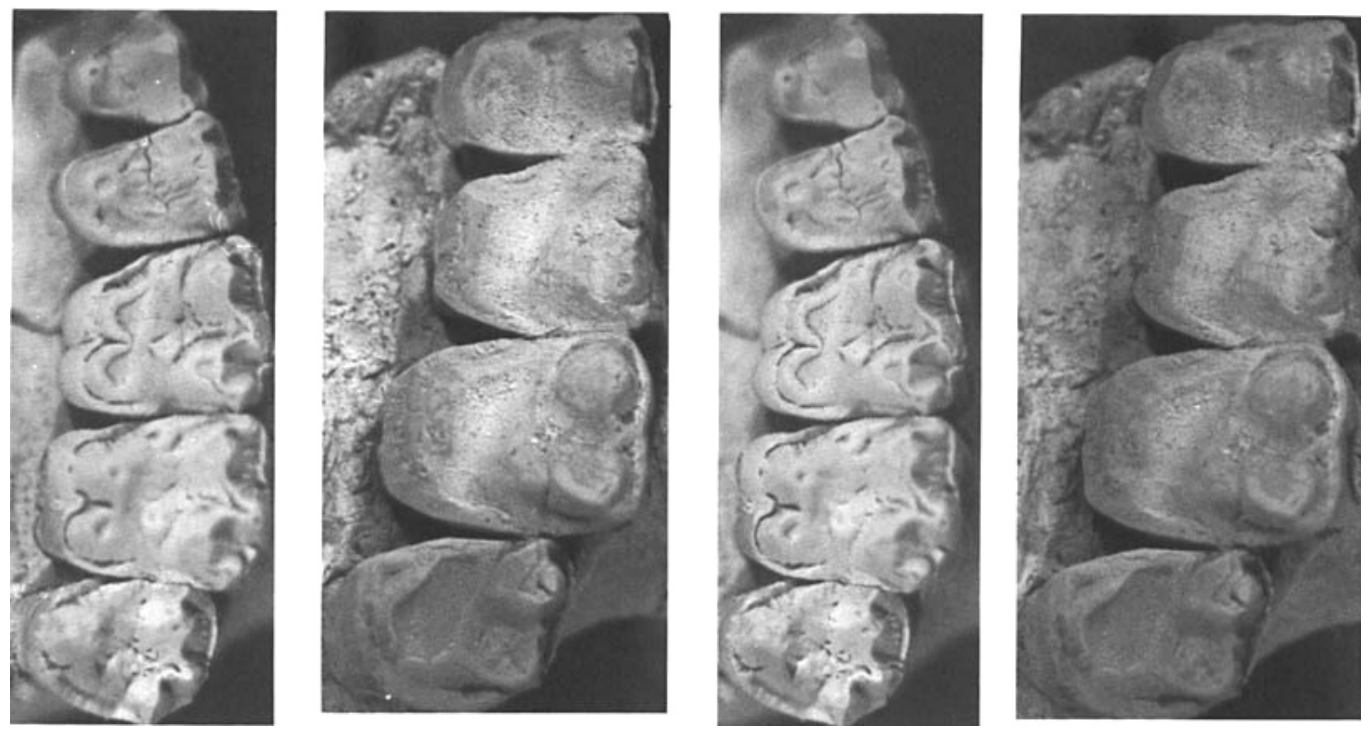

\section{A $-B$}

Fig. 9. Stereophotographs of left upper dentitions of (A) Notharctus tenebrosus (UM 32335, $\mathrm{P}^{3}-\mathrm{M}^{3}$ ) and (B) Hesperolemur actius (SDSNH 35233, holotype, $\mathbf{P}^{4}-\mathbf{M}^{3}$ ) in occlusal view. Scale $=2 \mathrm{~mm}$.

the largest molar, with $\mathrm{M}^{1}$ being noticeably smaller than $\mathbf{M}^{2}$ and $\mathbf{M}^{3}$ slightly smaller than $\mathrm{M}^{1}$. It is difficult to determine the position and relationships of upper molar protocones and hypocones with precision, but extensive comparisons with other adapiforms indicate that Hesperolemur almost certainly had a protocone fold and lacked a cingular hypocone. $\mathrm{M}^{1-2}$ have well-developed paracones and metacones that are separated by a rather wide, shallow valley formed by gently sloping postparacristae and premetacristae. $\mathrm{M}^{3}$ has a very weak, low metacone. Relatively robust metaconules are present on $\mathbf{M}^{1-2}$, while $\mathbf{M}^{3}$ has a relatively smaller metaconule. The presence and disposition of molar paraconules cannot be determined due to obscuring wear. $\mathrm{M}^{1}$ has a weakly formed mesostyle that is somewhat better developed on $\mathrm{M}^{2}$ and absent on $\mathrm{M}^{3}$. Relatively heavy 
mesial and distal cingula are present on all three molars as well as relatively weaker buccal and lingual cingula. Stylar shelves are essentially absent. $\mathrm{M}^{1}$ is longest buccally and tapers somewhat lingually but retains a generally square outline. $\mathbf{M}^{2}$ is wider and more rectangular in outline. $\mathbf{M}^{3}$ is generally squared but the mesiobuccal corner of the tooth is slightly distended, and the hypocone lobe is reduced compared to the other molars.

Comparing the upper dentition with other North American notharctines indicates that Hesperolemur is generally similar to most taxa but differs in important ways from each (Figs. 9, 10). Hesperolemur differs from Notharctus in having $\mathrm{P}^{4}$ with a more mesially and buccally placed protocone and a centrally placed paracone. Upper molars of Hesperolemur differ from those of Notharctus in having less well-developed mesostyles with little or no stylar shelf development and in lacking distinct hypocone lobes that are separated from the protocone by a distinct lingual groove (especially true of more derived Notharctus species). Hesperolemur differs from Smilodectes in having weaker mesostyles, in having very shallow trigon basins, and in having relatively larger hypocone lobes.

Hesperolemur differs from derived Cantius species in much the same manner as it does from Notharctus, but more primitive species of Cantius have weaker mesostyles and more mesial $\mathrm{P}^{4}$ protocones like those of Hesperolemur. Hesperolemur also has a more mesiodistally compressed $\mathrm{P}^{4}$ than most species of Cantius. Hesperolemur differs from Copelemur (C. tutus only) in lacking a welldeveloped mesostylar cusp (Hesperolemur has a crest-like mesostyle instead of an isolated cuspule), in lacking a lingually expanded protocone lobe, in having a weaker stylar shelf, in having a shallower trigon basin, and in having more bulbous and robust metaconules and stronger upper molar cingula. Hesperolemur differs from Pelycodus jarrovii in having upper molar mesostyles and in having the $\mathrm{M}^{3}$ paracone less buccally distended.

SDSNH 42415 is a right $\mathrm{M}_{3}$ referred to Hesperolemur actius (Fig. 10F). The protoconid and metaconid are widely spaced, with the metaconid taller, more basally inflated, and much more massive. The protoconid and metaconid are connected buccally by a welldeveloped crest. There is no paraconid, but a short, arcuate paracristid connects the mesial flanks of the protoconid and metaconid forming the mesial wall of a distinct trigonid fovea. There is a distinct, robust hypoconid that is connected to the postprotocristid by a sigmoid cristid obliqua. A small ectocingulid is present beneath the hypoflexid. A small entoconid and an elongate, faintly bilobate hypoconulid are present.

The $\mathrm{M}_{3}$ of Hesperolemur differs from that of Notharctus and Cantius (Fig. 10D,E) in having a smaller trigonid fovea with a shorter, more robust paracristid and no paraconid, in having a very massive metaconid and a more inflated protoconid, in having a weaker buccal cingulid, in lacking multiple entoconid cuspules, and in lacking the distinctive lingual extension of the postprotocristid at its juncture with the cristid obliqua. Hesperolemur differs from Copelemur in lacking a distinct paraconid (C. tutus has a paraconid: C. praetutus does not), in lacking an entoconid notch, in lacking the lingually positioned entoconid typical of Copelemur, and in having more massive and inflated protoconid and metaconid. C. praetutus shares a sigmoidal cristid obliquapostprotocristid flexure with Hesperolemur, while C. tutus has this complex less well developed.

The $\mathrm{M}_{3}$ of Hesperolemur differs from that of Pelycodus jarrovii in lacking a mesiodistally compressed trigonid, in lacking a paraconid, in having a sigmoid cristid obliquapostprotocristid flexure, in having a massive metaconid, and in having a better developed trigonid fovea. Hesperolemur differs from Smilodectes (Fig. 10C) in having the trigonid of $\mathrm{M}_{3}$ closed lingually by the paracristid, in having a much more massive metaconid and an inflated protoconid, in having a sigmoidal cristid obliqua-postprotocristid flexure, in having a shallower talonid basin, and in having a relatively smaller entoconid.

UCMP 113256, a broken left $\mathrm{M}_{2 \text { ? }}$, was described and figured by Lillegraven (1980) as Notharctus sp. near $N$. robustior. Although the talonid is damaged, the trigonid is nearly complete. The trigonid consists of a rela- 

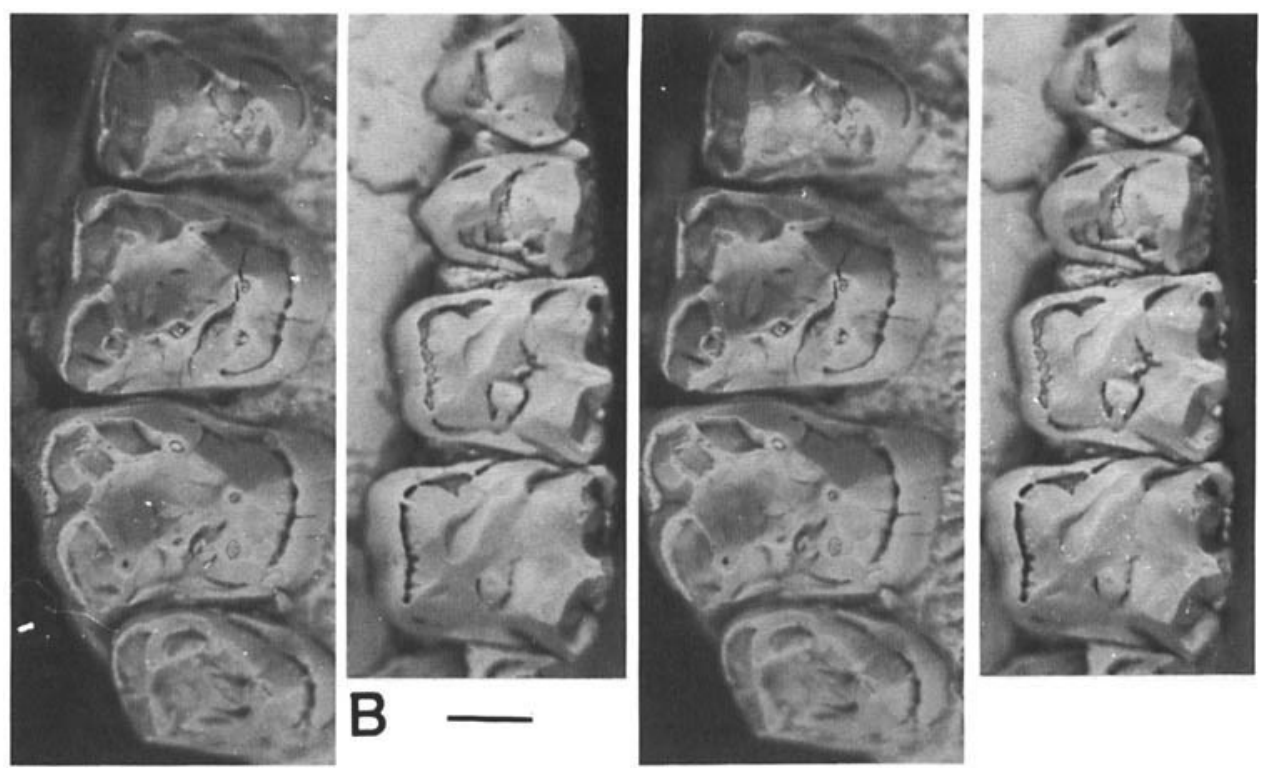

A -
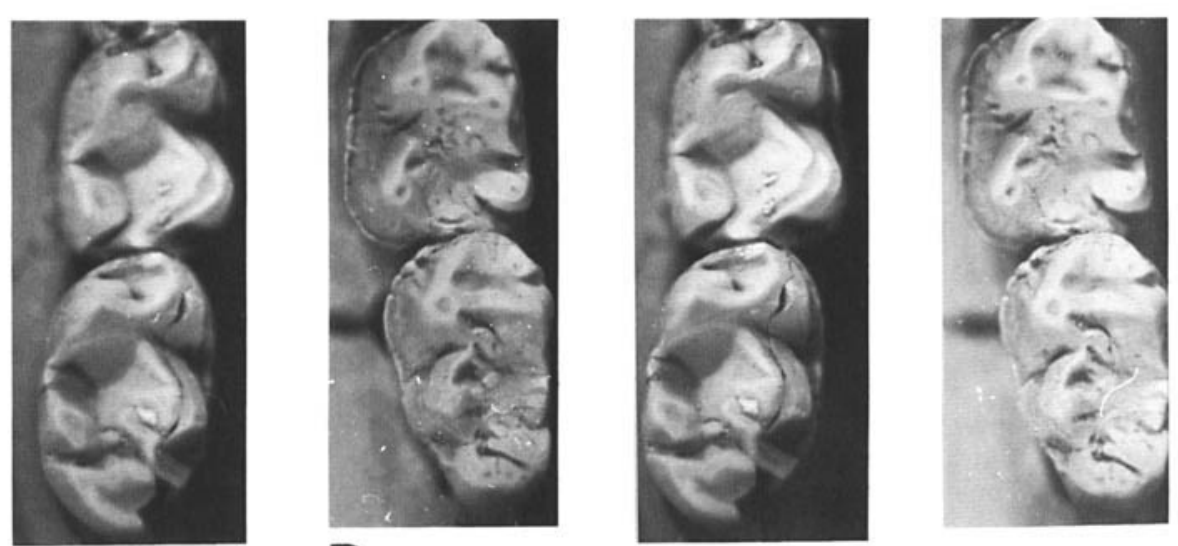

C

D -
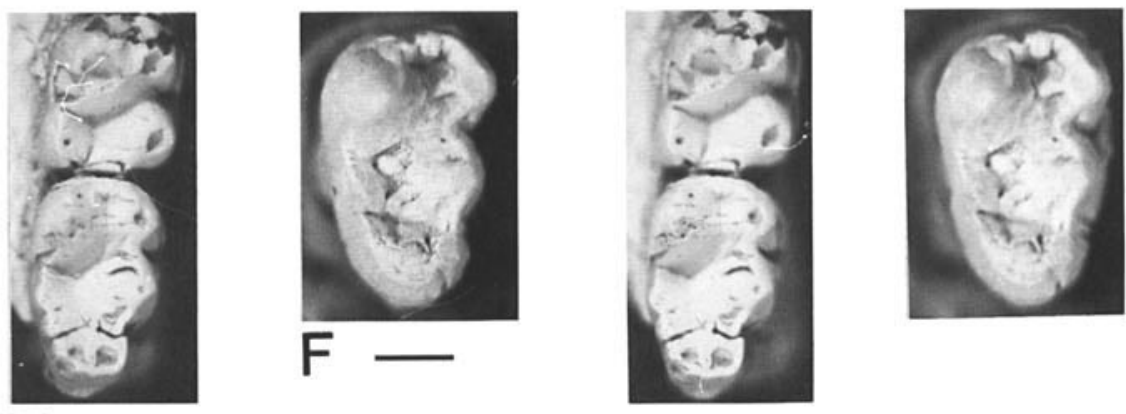

E - 
TABLE 2. Dental measurements Hesperolemur actius compared with selected North American notharctines and the cercamoniine Mahgarita stevensi ${ }^{1}$

\begin{tabular}{|c|c|c|c|c|c|}
\hline Genus/species & $\mathrm{P}^{4} \mathrm{~L} \times \mathrm{W}$ & $\mathbf{M}^{\mathrm{l}} \mathrm{L} \times \mathbf{W}$ & $\mathbf{M}^{2} \mathbf{L} \times \mathbf{W}$ & $\mathbf{M}^{3} \mathbf{L} \times \mathbf{W}$ & $\mathrm{M}_{3} \mathrm{~L} \times \mathrm{W}$ \\
\hline Hesperolemur actius & $4.4 \times 6.0(1)$ & $5.2 \times 6.2(1)$ & $5.3 \times 7.3(1)$ & $5.0 \times 6.2(1)$ & $6.9 \times 4.5(1)$ \\
\hline Notharctus tenebrosus & $4.8 \times 6.7(12)$ & $6.4 \times 7.8(16)$ & $6.4 \times 8.2(14)$ & $5.2 \times 6.9(10)$ & $6.9 \times 4.4(11)$ \\
\hline Notharctus robinsoni & $4.5 \times 6.6(3)$ & $6.0 \times 7.6(4)$ & $6.1 \times 8.0(3)$ & - & $6.8 \times 4.2(10)$ \\
\hline Smilodectes gracilis & $3.4 \times 4.2(5)$ & $4.4 \times 5.5(7)$ & $4.6 \times 6.0(9)$ & $4.0 \times 5.3(10)$ & $5.7 \times 3.5(10)$ \\
\hline Smilodectes megrewi & - & $4.4 \times 5.6(2)$ & $4.8 \times 6.1(3)$ & $4.2 \times 5.4(2)$ & $5.1 \times 3.6(2)$ \\
\hline Cantius abditus & $3.9 \times 5.3(5)$ & $4.9 \times 6.4(3)$ & $5.1 \times 7.6(4)$ & $4.0 \times 5.9(3)$ & $6.6 \times 4.3(7)$ \\
\hline Copelemur tutus & - & - & $5.5 \times 8.1(1)$ & - & - \\
\hline Copelemur praetutus & - & - & - & - & $5.3 \times 3.1(1)$ \\
\hline Pelycodus jarrovii & - & $5.5 \times 6.5(4)$ & $5.4 \times 7.2(2)$ & $4.8 \times 6.1(3)$ & $6.6 \times 4.4(2)$ \\
\hline Mahgarita stevensi & $2.9 \times 3.8(1)$ & $4.6 \times 4.5(1)$ & $4.0 \times 4.7(1)$ & $3.2 \times 4.4(1)$ & $4.2 \times 2.5(1)$ \\
\hline
\end{tabular}

${ }^{1}$ The number in parentheses $=\mathrm{N}$; measurement mean is given for samples larger than 1 .

tively robust protoconid widely separated from a massive, basally inflated metaconid and a short, relatively straight paracristid that connects the mesial flanks of the protoconid and metaconid. There is no paraconid developed. All of these features are shared with SDSNH 42415, and therefore this specimen is referred to $H$. actius.

Measurements of the teeth of Hesperolemur actius are presented in Table 2.

\section{RELATIONSHIPS OF HESPEROLEMUR}

Hesperolemur is the latest surviving notharctine primate known. The only later adapiform known from North America is the cercamoniine notharctid Mahgarita stevensi from the Skyline Channels, Devil's Graveyard Formation, Duchesnean Land-Mammal Age (late Eocene) of southwestern Texas (Wilson and Szalay, 1976; Rasmussen, 1990). Comparison of Hesperolemur and Mahgarita does not appear to support a close relationship. Mahgarita and Hesperolemur do share an apparent lack of a stapedial artery along with a large promontory artery and possibly the presence of a "fused" ectotympanic anulus (a complete anular bridge [see Rasmussen, 1990]). These character states are shared in common with primitive anthro-

Fig. 10. Stereophotographs of representative notharctine primate dentitions in occlusal view. A: Right $\mathrm{P}^{4}-\mathrm{M}^{3}$ of Cantius abditus (UM 88239). B: Left $\mathrm{P}^{3}-\mathbf{M}^{2}$ of Smilodectes gracilis (UM 100000). C: Right $\mathrm{M}_{2 \pi}$ of Smilodectes gracilis (UM 100000). D: Left $\mathbf{M}_{2-3}$ of Notharctus robinsoni (UM 94853). E: Right $\mathbf{M}_{2-3}$ of Cantius abditus (UM 97091). F: Right $\mathrm{M}_{3}$ of Hesperolemur actius (SDSNH 42415). Scale $=2 \mathrm{~mm}$. poids such as Aegyptopithecus (Rasmussen, 1990; Simons and Rasmussen, 1989; but also see Ross, 1994). However, as pointed out above, relatively small stapedial arteries also apear to be the rule in most known adapiforms, so this character state could be viewed as primitive (symplesiomorphic) for the infraorder. The apparent presence of an anteriorly fused ectotympanic and the lack of a stapedial artery may both represent synapomorphies for Mahgarita and Hesperolemur, but the evidence is such that definitive interpretation remains difficult.

In nearly all other dental and cranial features, Hesperolemur and Mahgarita appear quite different (Wilson and Szalay, 1976; Rasmussen, 1990). Mahgarita, like all other known Eocene primates, had a bony tube that carried the promontory artery through the tympanic cavity. Mahgarita has true (cingular) hypocones on upper molars in contrast with all other North American notharctids and lacks upper molar mesostyles (unlike Hesperolemur). Mahgarita also differs from Hesperolemur in having the following: more cuspate teeth that lack robust, bulbous cusps; $\mathrm{P}^{4}$ with a centrally placed protocone and more steeply sloping pre- and postparacrista; lower molars with metaconid positioned posterior to the protoconid and lacking basal inflation; lower molar trigonids that are open lingually with a short, sloping paracristid and a very shallow, small trigonid fovea; and lower molars with a straight cristid obliqua and a well-developed entoconid positioned posterior to the hypoconid.

Hesperolemur shares some character states with adapids. Like Adapis parisiensis 
and Leptadapis magnus, the skull of $H$. actius has frontal lines that converge anteriorly and are confluent with a well-developed sagittal crest. Hesperolemur also shares a relatively large dorsolateral expansion of the squamosal with Adapis. Hesperolemur differs dentally from Adapis and Leptadapis in having upper molars with postprotocingula and well-developed metaconules, a premolariform $\mathrm{P}^{4}$, closed lower molar trigonids, and basally inflated protoconids and metaconids that are opposite one another, not offset with the metaconid posterior to the protoconid.

Hesperolemur is also similar to European cercamoniines and European Cantius eppsi and Cantius savage in some ways. Like European Cantius species, Hesperolemur has upper molars with well-developed metaconules and lower third molars with closed trigonids, small entoconids, flexed cristid obliquae, and relatively inflated trigonid cusps. As in all cercamoniines except Donrussellia, Hesperolemur has lower molars that lack a paraconid, but it differs from most cercamoniines (except Periconodon and Agerinia) by having lower molar trigonids closed lingually instead of being broadly open as in the former. Caenopithecus lemuroides shares upper molar mesostyles and lower molar hypoconulids with Hesperolemur but differs in most other dental details. Like Protoadapis, Hesperolemur has relatively bulbous cusps, but Protoadapis lacks the basal inflation of lower molar cusps exhibited by Hesperolemur. Hesperolemur differs from all cercamoniines in having a protocone fold and a well-developed metaconule on upper molars.

Among North American notharctines, Hesperolemur seems to be most similar to Pelycodus, Notharctus, and Cantius. Like Notharctus, $H$. actius has relatively broad frontals and shares similar basisphenoid and basioccipital morphologies. Dentally, $H$. actius shares a flexed cristid obliqua on $\mathrm{M}_{3}$ with Notharctus, Cantius, Pelycodus, and some species of Copelemur. Hesperolemur shares relatively heavy upper molar cingula with Pelycodus as well as relatively robust and basally inflated lower molar protoconids and metaconids and a small, single-cusped entoconid on $\mathrm{M}_{3}$. Hesperolemur shares in- flated lower molar protoconids and metaconids and relatively weak upper molar mesostyles with some derived species of Cantius (from both North America and Europe). Hesperolemur seems more distantly related to Smilodectes and Copelemur among North American notharctines.

An analysis of the relationships among the seven North American adapiforms was carried out using the branch-and-bound option of PAUP (Phylogenetic Analysis Using Parsimony, version 3.1.1 [Swofford, 1993]). This analysis is based on 21 unordered cranial and dental characters (Tables 3,4) using the primitive European cercamoniine Donrussellia as the outgroup to root trees. No a priori or a posteriori weighting of characters was attempted. Three most parsimonious trees were derived from the character matrix, each consisting of 29 steps with a consistency index of 0.724 and a retention index of 0.600 . Figure 11 presents one of the three hypothesized branching sequences for North American notharctines and also represents the 50\% Majority Rule Consensus Tree. This cladogram differs from the strict consensus tree by resolving a polytomy consisting of all North American notharctines except Cantius. In all trees Mahgarita and Adapis form a clade that is the sister group of North American notharctines, and Cantius is the sister.taxon to all other North American notharctines. Smilodectes and Copelemur are more closely related to each other than to any other notharctine in all trees. In two of the three trees, Hesperolemur is the sister taxon of Pelycodus, while in the third Hesperolemur is the sister to a clade consisting of Notharctus, Smilodectes, and $\mathrm{Co}$ pelemur.

\section{SOUTHERN CALIFORNIAN PRIMATE FAUNAS}

Middle to late Eocene primates are well represented in southern California from both San Diego and Ventura counties (Stock, 1933a, 1934a; Gazin, 1958; Szalay, 1976; Lillegraven, 1980; Kelly, 1990; Mason, 1990; Honey, 1990; Gunnell, 1995). Two separate regions in San Diego County have middle to late Eocene rocks that have produced primate specimens. In the northwestern part 
TABLE 3. Characters and character states used to construct matrix shown in Table $4^{1}$

\begin{tabular}{|c|c|c|c|}
\hline Character number & Character & Alternative state 0 & Alternative state 1 \\
\hline $\mathrm{C} 1$ & Bony internal carotid canals & Absent & Present \\
\hline $\mathrm{C} 2$ & Petrosal anular bridge & Partial & Complete \\
\hline C3 & Ectotympanic & "Free ring" & "Partially fused" \\
\hline $\mathrm{C} 4$ & Lacrimal canal & Outside orbit & Within orbit \\
\hline $\mathrm{C} 5$ & Frontals (width) & Narrow & Broad \\
\hline C6 & Frontals (shape) & Flat & Inflated \\
\hline $\mathrm{C} 7$ & Basisphenoid & No bullar overlap & Overlaps bulla \\
\hline $\mathrm{C} 8$ & Basioccipital & No bullar overlap & Overlaps bulla \\
\hline $\mathrm{C9}$ & $\mathrm{P}^{4}$ protocone & Widely separated ${ }^{1}$ & Appressed to paracone \\
\hline C10 & Molar hypocone & Cingular & Protocone fold \\
\hline C11 & Molar metaconule & Present $^{1}$ & Absent \\
\hline C12 & Molar mesostyle & Absent ${ }^{1}$ & Present \\
\hline $\mathrm{C} 13$ & Mesostyle form & Cuspate & Crescentic-arcuate \\
\hline C14 & Molar hypocone lobe & Continuous & Separate from protocone \\
\hline C15 & Molar protoconid & Not basally inflated ${ }^{1}$ & Basally inflated \\
\hline C16 & Molar metaconid & Not basally inflated ${ }^{1}$ & Basally inflated \\
\hline $\mathrm{C} 17$ & Molar paraconid & Present $^{1}$ & Absent \\
\hline $\mathrm{C} 18$ & Molar paracristid & Not continuous ${ }^{1}$ & Continuous with metaconid \\
\hline $\mathrm{C} 19$ & $\mathrm{M}_{3}$ cristid obliqua & Straight ${ }^{1}$ & Sigmoidal \\
\hline $\mathrm{C} 20$ & $\mathrm{P}_{4}$ shape & Premolariform ${ }^{1}$ & Molariform \\
\hline $\mathrm{C} 21$ & Molar entoconid notch & Absent ${ }^{1}$ & Present \\
\hline
\end{tabular}

${ }^{1}$ Character state alternative present in outgroup Donrussellia.

TABLE 4. Character state matrix for the seven North American adapiform genera based on 21 cranial and dental characters (see Table 3)

\begin{tabular}{|c|c|c|c|c|c|c|c|c|c|c|c|c|c|c|c|c|c|c|c|c|c|}
\hline Taxon & $\mathrm{C} 1$ & $\mathrm{C} 2$ & $\mathrm{C} 3$ & $\mathrm{C} 4$ & $\mathrm{C5}$ & $\mathrm{C} 6$ & $\mathrm{C} 7$ & $\mathrm{C} 8$ & $\mathrm{C9}$ & C10 & C11 & C12 & C13 & $\mathrm{C} 14$ & C15 & C16 & C17 & C18 & $\mathrm{C} 19$ & $\mathrm{C} 20$ & C21 \\
\hline Hesperolemur & 0 & 1 & 1 & 1 & 1 & 0 & 0 & 0 & 1 & 1 & 0 & 1 & 1 & 0 & 1 & 1 & 1 & 1 & 1 & 0 & 0 \\
\hline Notharctus & 1 & 0 & 0 & 1 & 1 & 0 & 0 & 1 & 0 & 1 & 0 & 1 & 1 & 1 & 0 & 1 & 0 & 0 & 1 & 0 & 0 \\
\hline Smilodectes & 1 & 0 & 0 & 1 & 1 & 1 & 1 & 1 & 0 & 1 & 0 & 1 & 1 & 0 & 0 & 0 & 1 & 0 & 0 & 0 & 1 \\
\hline Cantius & $?$ & $?$ & $?$ & 0 & 0 & 0 & $?$ & $?$ & 0 & 1 & 0 & 0 & $?$ & 0 & 0 & 0 & 0 & 0 & 1 & 0 & 0 \\
\hline Copelemur & $?$ & $?$ & $?$ & $?$ & $?$ & $?$ & $?$ & $?$ & 0 & 1 & 0 & 1 & 0 & 0 & 0 & 0 & 0 & 0 & 1 & 0 & 1 \\
\hline Pelycodus & $?$ & $?$ & $?$ & $?$ & $?$ & $?$ & $?$ & $?$ & 0 & 1 & 0 & 0 & $?$ & 0 & 1 & 1 & 0 & 0 & 1 & 0 & 0 \\
\hline Mahgarita & 1 & 1 & 1 & 0 & $?$ & $?$ & 0 & 0 & 0 & 0 & 0 & 0 & $?$ & $?$ & 0 & 0 & 1 & 0 & 0 & 0 & 0 \\
\hline Adapis & 1 & 0 & 0 & 1 & 0 & 0 & 0 & 0 & 0 & 0 & 1 & 0 & $?$ & $?$ & 0 & 0 & 1 & 0 & 0 & 1 & 0 \\
\hline Donrussellia & $?$ & $?$ & $?$ & $?$ & $?$ & $?$ & $?$ & $?$ & 0 & 0 & 0 & 0 & $?$ & $?$ & 0 & 0 & 0 & 0 & 0 & 0 & 0 \\
\hline
\end{tabular}

${ }^{1}$ The primitive European cercamoniine adapiform Donrussellia is used as the outgroup.

of San Diego County the Lower and Upper units of the Santiago Formation contain five local faunas ranging in age from early Uintan to early Duchesnean (Walsh, 1991). In the Poway/Greater San Diego area a series of at least five rock units spans the early to late Uintan (Kennedy and Moore, 1971; Peterson and Kennedy, 1974; Kennedy and Peterson, 1975; Walsh, 1991, personal communication). In Ventura County, Kelly (1990) and Kelly et al. (1991) have recently revised the biostratigraphy of the Eocene portion of the Sespe Formation. These authors recognize five local faunas spanning the late Uintan and Duchesnean, each of which contains primate taxa.

Figure 12 summarizes the distribution of primate taxa in San Diego and Ventura counties. By far the greatest number of primate taxa known from southern California come from the Poway fauna of early Uintan age in San Diego County. At least nine different primates are found in these rocks. All but two taxa are referable to omomyid primates, and most are represented by genera also known from earlier (Bridgerian) rocks in the interior of western North America (the exceptions being Stockia powayensis, whose ancestry can be linked to taxa in Wyoming and Utah [Honey, 1990; Gunnell, 1995], and Ourayia, a taxon also known from the Uintan of the western interior).

One adapiform primate was described from the early Uintan Poway faunas by Lillegraven (1980). It is represented by a single maxilla (UCMP 113210) containing $\mathrm{M}^{1-2}$ and 


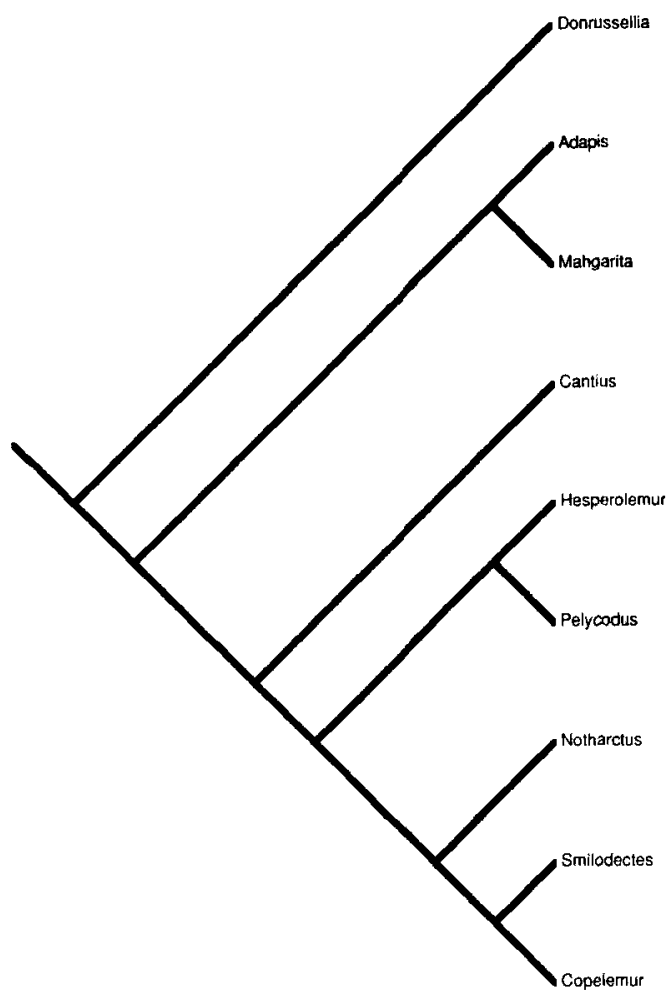

Fig. 11. Cladogram depicting one possible branching sequence for North American notharctine primates using the primitive cercamoniine Donrussellia as outgroup. This also represents the 50\% Majority Rule Consensus Tree. The analysis is based on 21 unordered cranial and dental characters (see Table 3) and represents one of three most parsimonious trees obtained by PAUP 3.1.1 using the branch-and-bound option on the resulting data matrix (see Table 4). Tree length is 29 steps; consistency index $=0.724$; retention index $=$ 0.600 .

a broken $\mathbf{M}^{3}$. Lillegraven (1980) compared this specimen carefully with Hemiacodon and "Pelycodus" (now Cantius) and concluded that UCMP 113210 showed greater overall similarity to "Pelycodus" (=Cantius). Upon further consideration, I believe a third possibility exists. Comparisons of stereophotographs of UCMP 113210 with other omomyid taxa leads to the conclusion that this specimen represents a species of Macrotarsius, close to the recently described $M$. roederi (Kelly, 1990) from the Sespe Formation.

UCMP 113210 differs from Macrotarsius most notably in lacking well-developed mes- ostyles on upper molars (Robinson, 1968; Krishtalka, 1978). In other features noted by Lillegraven (1980) - the broadly rounded anterior and posterior buccal corners, the lower, more rounded cusps and crests, the cingular development of the hypocone, and the presence of small pericones on $\mathrm{M}^{1-2}$ UCMP 113210 is very similar to Macrotar. sius. In addition, both UCMP 113210 and Macrotarsius share a broad, well-developed stylar shelf.

The absence of molar mesostyles does not rule out inclusion of UCMP 113210 in Macrotarsius. $M$. roederi from the Brea Canyon Local Fauna, while only known from a single lower jaw, has molar morphology suggesting that upper molars may have lacked or had only small mesostyles. During mastication the postcristid and hypoconulid regions of the lower molars shear along surfaces formed by the premetacrista and mesostyle of the upper molars. In Macrotarsius siegerti (CM 15056, 18646), where a well-developed mesostyle exists, the postcristid and hypoconulid of the lower molars are well developed, closing off the posterior end of the talonid (Krishtalka, 1978). Kelly (1990) describes $M$. roederi lower molars as lacking hypoconulids (except on $\mathrm{M}_{3}$ ) and instead as having a notch in the postcristid where the hypoconulid would normally be found. This suggests that $M$. roederi upper molars may not have had mesostyles. If interpreted correctly, this suggests that UCMP 113210 may well represent a specimen of $M$. roederi or a closely related taxon. In any event, UCMP 113210 is better interpreted as an omomyid than an adapiform, leaving Hesperolemur as the sole adapiform primate known from southern California.

\section{BIOGEOGRAPHY AND PALEOCLIMATES}

Lillegraven (1979) has hypothesized that mammalian migration in the middle Eocene between southern California and the western interior was accomplished via a lowland route, the Sevier orogenic belt, that extended from southern California through northern Arizona and southern Nevada into Utah and Wyoming during the middle Eocene. Early Uintan mammalian faunas are similar in taxonomic makeup from both the western 


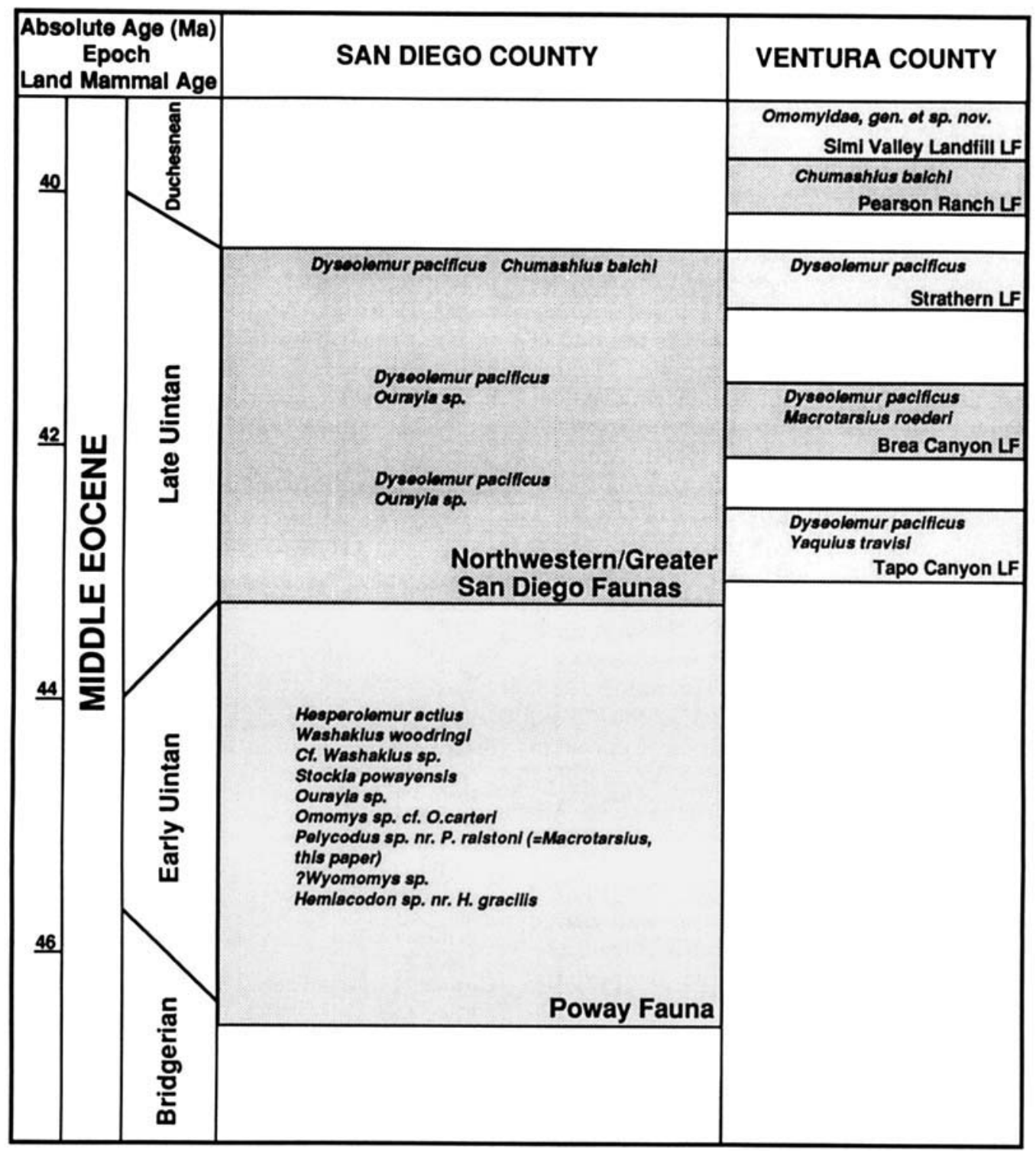

Fig. 12. Stratigraphic distribution of middle Eocene primate taxa from San Diego and Ventura counties (Golz and Lillegraven, 1977; Lillegraven, 1980; Kelly et al., 1991; Walsh, 1991).

interior and southern California. By the later Uintan, notable faunal differences occur between these areas, suggesting the closure of the Sevier orogenic belt leading to the development of more endemic faunas in southern California and the western interior (Lillegraven, 1979). Emry (1990) has recently described a middle Bridgerian fauna from Nevada that shares taxa in common with both California and the western interior, suggesting that some mammalian migration was possible between these areas, at least in the Bridgerian.

The climate along the southern California coastal lowlands during the middle Eocene ranged from tropical in the early Uintan to somewhat more arid and subtropical by the latter part of the Uintan (Lillegraven, 1979). 
The western interior paleoclimate had begun to deteriorate by the early Uintan from a tropical, moist environment in the Bridgerian to a drier, more open environment in the Uintan, followed by a collapse of paleotemperatures in the latest Eocene/ earliest Oligocene (Berggren and Prothero, 1992; Leopold et al., 1992; Wolfe, 1992). The warmer coastal lowlands may have served as a refuge area for tropical dwelling primates during the early Uintan. As paleoclimates continued to deteriorate towards the end of the Uintan in California, primates became less and less important members of paleocommunities. By the latest Eocene primates were essentially gone from North America with only the rare Mahgarita and Rooneyia, along with isolated occurrences of Omomys, Macrotarsius, and Ourayia (West, 1982; Westgate, 1988, 1990), being represented from the southern part of Texas. The only possible later occurrence of a North American primate is the enigmatic Arikareean genus Ekgmowechashala (Macdonald, 1963, 1970; Rose and Rensberger, 1983) from South Dakota and Oregon (recently placed in the order ?Dermoptera by McKenna, 1990).

Hesperolemur, as with the many omomyid taxa known from southern California, seems to have found refuge in this warm, coastal region during the later portion of the middle Eocene. Hesperolemur may have migrated from the western interior, either from the Wyoming/Utah/Colorado area or perhaps from New Mexico along the Sevier orogenic belt during the late Bridgerian, reaching California by the early Uintan. Alternatively, Hesperolemur may have evolved from an unknown adapiform stock previously present in southern California.

\section{ACKNOWLEDGMENTS}

I thank T.A. Démére for providing me the opportunity to study and describe Hesperolemur and $\mathrm{S}$. Walsh for bringing the specimens of Hesperolemur to my attention. I thank both for providing information concerning the stratigraphy and faunas of the San Diego area. I thank P.D. Gingerich, K.D. Rose, and D.T. Rasmussen for discussions concerning relationships and morphology among Eocene adapiforms. Two anonymous reviewers provided many helpful suggestions and comments. I thank P.D. Gingerich for access to his large collection of North American and European adapiform casts and K.C. Beard (Carnegie Museum), T.M. Bown (USGS, Denver), J.W. Froelich (University of New Mexico), M.C. McKenna (American Museum of Natural History), and K.D. Rose (Johns Hopkins University) for providing casts of North American adapiforms. B. Miljour and P. D. Gingerich aided in the preparation of photographs, and B. Miljour prepared all line drawings. M.D. Uhen provided assistance in phylogenetic analysis. This research was supported in part by a grant from the National Geographic Society to the author.

\section{LITERATURE CITED}

Beard KC (1988) The phylogenetic significance of strepsirhinism in Paleogene primates. Int. J. Primatol. 9:83-96.

Beard KC, and MacPhee RDE (1994) Cranial anatomy of Shoshonius and the antiquity of Anthropoidea. In JF Fleagle and RF Kay (eds.): Anthropoid Origins. New York: Plenum Press, pp. 55-97.

Berggren WA, and Prothero DR (1992) Eocene-Oligocene climatic and biotic evolution: An overview. In DR Prothero and WA Berggren (eds.): Eocene-Oligocene Climatic and Biotic Evolution. Princeton: Princeton University Press, pp. 1-28.

Cartmill M (1975) Strepsirhine basicranial structures and the affinities of the Cheirogaleidae. In WP Luckett and FS Szalay (eds.): Phylogeny of the Primates: A multidisciplinary approach. New York: Plenum, pp. 313-354.

Cartmill M (1994) Anatomy, antinomies, and the problem of anthropoid origins. In JF Fleagle and RF Kay (eds.): Anthropoid Origins. New York: Plenum Press, pp. 549-566.

Cartmill M, and Kay RF (1978) Cranio-dental morphology, tarsier affinities, and primate suborders. In DJ Chivers and KA Joysey (eds.): Recent Advances in Primatology, Vol. 3. London: Academic Press, pp. 205-213.

Emry RJ (1990) Mammals of the Bridgerian (middle Eocene) Elderberry Canyon local fauna of eastern $\mathrm{Ne}$ vada. In TM Bown and KD Rose (eds.): Dawn of the Age of Mammals in the northern part of the Rocky Mountain Interior, North America. Spec. Pap. Geol. Soc. Am. 243:187-210.

Franzen JL (1987) Ein neuer Primate aus dem Mitteleozän der Grube Messel (Deutschland, S-Hessen). In S Schaal (ed.): Forschungsergebnisse zu Grabungen in der Grube Messel bei Darmstadt. Cour. Forsch.-Inst. Senckenberg 91:151-187.

Gazin CL (1958) A review of the middle and upper Eocene primates of North America. Smithson. Misc. Collns. 136:1-112.

Gingerich PD (1973) Anatomy of the temporal bone in 
the Oligocene anthropoid Apidium and the origin of Anthropoidea. Folia Primatol. 19:329-337.

Gingerich PD (1981a) Cranial morphology and adaptations in Eocene Adapidae. I. Sexual dimorphism in Adapis magnus and Adapis parisiensis. Am. J. Phys. Anthropol. 56:217-234.

Gingerich PD (1981b) Early Cenozoic Omomyidae and the evolutionary history of tarsiiform primates. J. Hum. Evol. 10:345-374.

Gingerich PD, and Martin RD (1981) Cranial morphology and adaptations in Eocene Adapidae. II. The Cambridge skull of Adapis parisiensis. Am. J. Phys. Anthropol. 56:235-257.

Golz DJ (1976) Eocene Artiodactyla of southern California. Sci. Bull. Nat. Hist. Mus. Los Angeles Co. 26:1-85.

Golz DJ, and Lillegraven JA (1977) Summary of known occurrences of terrestrial vertebrates from Eocene strata of southern California. Contr. Geol., Univ. Wyo. 15:43-65.

Gregory WK (1920) On the structure and relations of Notharctus, an American Eocene primate. Mem. Am. Mus. Nat. Hist. 3:49-243.

Gunnell GF (1995) Omomyid primates (Tarsiiformes) from the Bridger Formation, middle Eocene, southern Green River Basin, Wyoming. J. Hum. Evol. 28:147187.

Honey JG (1990) New washakiin primates (Omomyidae) from the Eocene of Wyoming and Colorado, and comments on the evolution of the Washakiini. J. Vert. Paleontol. 10:206-221.

Kelly TS (1990) Biostratigraphy of Uintan and Duchesnean land mammal assemblages from the Middle Member of the Sespe Formation, Simi Valley, California. Contr. Sci. Nat. Hist. Mus. Los Angeles Co. 419:1-42.

Kelly TS, Lander EB, Whistler DP, Roeder MA, and Reynolds RE (1991) Preliminary report on a paleontologic investigation of the Lower and Middle Members, Sespe Formation, Simi Valley Landfill, Ventura County, California. PaleoBios 13:1-13.

Kennedy MP, and Moore GW (1971) Stratigraphic relations of Upper Cretaceous and Eocene formations, San Diego coastal region, California. Bull. Am. Assoc. Petrol. Geol. 55:709-722.

Kennedy MP, and Peterson GL (1975) Geology of the eastern San Diego Metropolitan area, California. Bull. Calif. Div. Mines and Geol. 200-B:45-56.

Krishtalka L (1978) Paleontology and geology of the Badwater Creek Area, central Wyoming. Part 15. Review of the late Eocene primates from Wyoming and Utah, and the Plesitarsiiformes. Ann. Carnegie Mus. 47:335-360.

Leopold EB, Liu G, and Clay-Poole S (1992) Low-biomass vegetation in the Oligocene? In DR Prothero and WA Berggren (eds.): Eocene-Oligocene Climatic and Biotic Evolution. Princeton: Princeton University Press, pp. 399-420.

Lillegraven JA (1976) Didelphids (Marsupialia) and Uintasorex (?Primates) from later Eocene sediments of San Diego County, California. Trans. San Diego Soc. Nat. Hist. 18:85-112.

Lillegraven JA (1979) A biogeographical problem involving comparisons of later Eocene terrestrial vertebrate faunas of western North America. In $\mathbf{J}$ Gray and AJ
Boucot (eds.): Historical Biogeography, Plate Tectonics, and the Changing Environment. Corvallis: Oregon State University Press, pp. 333-347.

Lillegraven JA (1980) Primates from later Eocene rocks of southern California. J. Mammal. 61:181-204.

Macdonald JR (1963) The Miocene faunas from the Wounded Knee area of western South Dakota. Bull. Am. Mus. Nat. Hist. 125:139-238.

Macdonald JR (1970). Review of the Miocene Wounded Knee faunas of southwestern South Dakota. Sci. Bull. Mus. Nat. Hist. Los Angeles Co. 8:1-82.

MacPhee RDE (1981) Auditory regions of primates and eutherian insectivores. Morphology, ontogeny, and character analysis. Contr. Primatol. 18:1-282.

MacPhee RDE (1987) Basicranial morphology and ontogeny of the extinct giant lemur Megaladapis. Am. J. Phys. Anthropol. 74:333-355.

MacPhee RDE, and Cartmill M (1986) Basicranial structures and primate systematics. In DR Swindler and J Erwin (eds.): Comparative Primate Biology, Vol. 1: Systematics, Evolution, and Anatomy. New York: Alan R Liss, Inc., pp. 219-275.

Mason MA (1990) New fossil primates from the Uintan (Eocene) of southern California. PaleoBios 13:1-7.

McKenna MC (1990) Plagiomenids (Mammalia: ?Dermoptera) from the Oligocene of Oregon, Montana, and South Dakota, and middle Eocene of northwestern Wyoming. In TM Bown and KD Rose (eds.): Dawn of the Age of Mammals in the northern part of the Rocky Mountain Interior, North America. Spec. Pap. Geol. Soc. Am. 243:211-234.

Peterson GL, and Kennedy MP (1974) Lithostratigraphic variations in the Poway Group near San Diego, California. Trans. San Diego Soc. Nat. Hist. 17:251-258.

Rasmussen DT (1986) Anthropoid origins: A possible solution to the Adapidae-Omomyidae paradox. J. Hum. Evol. 15:1-12.

Rasmussen DT (1990) The phylogenetic position of Mahgarita stevensi: Protoanthropoid or Lemuroid? Int. J. Primatol. 11:439-469.

Rasmussen DT (1994) The different meanings of a tarsioid-anthropoid clade and a new model of anthropoid origins. In JF Fleagle and RF Kay (eds.): Anthropoid Origins. New York: Plenum Press, pp. 335-360.

Robinson P (1968) The Paleontology and geology of the Badwater Creek Area, central Wyoming. Part 4. Late Eocene primates from Badwater, Wyoming, with a discussion of material from Utah. Ann. Carnegie Mus. 39:307-326

Rose KD, and Rensberger JM (1983) Upper dentition of Ekgmowechashala (Omomyid Primate) from the John Day Formation, Oligo-Miocene of Oregon. Folia Primatol. 41:102-111.

Ross C (1994) The craniofacial evidence for anthropoid and tarsier relationships. In JF Fleagle and RF Kay (eds.): Anthropoid Origins. New York: Plenum Press, pp. 469-547.

Simons EL, and Rasmussen DT (1989) Cranial morphology of Aegyptopithecus and Tarsius and the question of the tarsier-anthropoidean clade. Am. J. Phys. Anthropol. 79:1-23.

Simpson GG (1940) Studies on the earliest primates. Bull. Am. Mus. Nat. Hist. 77:185-212.

Stehlin HG (1912) Die Säugetiere des schweizerischen 
Eocäens: Adapis. Abh. Schweiz. Paläont. Ges. 38: 1165-1298.

Stock C (1932) Eocene land mammals on the Pacific coast. Proc. Natl. Acad. Sci. U.S.A. 18:518-523.

Stock C (1933a) Hyaenodontidae of the upper Eocene of California. Proc. Natl. Acad. Sci. U.S.A. 19:434-440.

Stock C (1933b) A miacid from the Sespe upper Eocene, California. Proc. Natl. Acad. Sci. U.S.A. 19:481-486.

Stock C (1933c) An amynodont skull from the Sespe deposits, California. Proc. Natl. Acad. Sci. U.S.A. 19:762-767.

Stock C (1933d) An Eocene primate from California. Proc. Natl. Acad. Sci. U.S.A. 19:954-959.

Stock C (1934a) A second Eocene primate from California. Proc. Natl. Acad. Sci. U.S.A. 20:150-154.

Stock C (1934b) Microsyopsinae and Hyopsodontidae in the Sespe upper Eocene, California. Proc. Natl. Acad. Sci. U.S.A. 20:349-354.

Stock C (1934c) New Creodonta from the Sespe upper Eocene, California. Proc. Natl. Acad. Sci. U.S.A. 20:423-427.

Stock C (1934d) A hypertragulid from the Sespe upper Eocene, California. Proc. Natl. Acad. Sci. U.S.A. 20:625-629.

Stock C (1935a) New genus of rodent from the Sespe Eocene. Bull. Geol. Soc. Am. 46:61-68.

Stock C (1935b) Plesiomiacis, a new creodont from the Sespe upper Eocene, California. Proc. Natl. Acad. Sci. U.S.A. 21:119-122.

Stock C (1935c) Insectivora from the Sespe uppermost Eocene, California. Proc, Natl. Acad. Sci. U.S.A. 21:214-219.

Stock C (1935d) Titanothere remains from the Sespe of California. Proc. Natl. Acad. Sci. U.S.A. 21:456-462.

Stock C (1936a) Sespe Eocene didelphids. Proc. Natl. Acad. Sci. U.S.A. 22:122-124.

Stock C (1936b) Hesperomeryx, a new artiodactyl from the Sespe Eocene, California. Proc. Nati. Acad. Sci. U.S.A. 22:177-182.

Stock C (1936c) Perissodactyla of the Sespe Eocene, California. Proc. Natl Acad. Sci. U.S.A. 22:260-265.

Stock C (1937) An Eocene titanothere from San Diego County, California, with remarks on the age of the Poway Conglomerate. Proc. Natl. Acad. Sci. U.S.A. $23: 48-53$.

Stock C (1938) A tarsiid primate and a mixodectid from the PowayEocene, California. Proc. Natl. Acad. Sci. U.S.A. 24:288-293.

Swofford D (1993) PAUP (Phylogenetic Analysis Using Parsimony), version 3.1.1. Computer program distrib- uted by Illinois History Survey, Champagne, IL (program licensed to DC Fisher).

Szalay FS (1975) Phylogeny of primate higher taxa: The basicranial evidence. In WP Luckett and FS Szalay (eds.): Phylogeny of the Primates: A multidisciplinary approach. New York: Plenum, pp. 91-125.

Szalay FS (1976) Systematics of the Omomyidae (Tarsiiformes, Primates). Taxonomy, phylogeny, and adaptations. Bull. Am. Mus. Nat. Hist. 156:163-449.

Szalay FS, and Delson E (1979) Evolutionary History of the Primates. New York: Academic Press.

Trouessart E-L (1879) Catalogue Systématique, Synonymique et Géographique des Mammiferes Vivants et Fossiles. I: Primates. (Simiae, Prosimiae, Chiroptera); II: Insectivora. Paris: E. Deyrolles.

Walsh SL (1991) Eocene mammal faunas of San Diego County. In PL Abbott and JA May (eds.): Eocene Geologic History San Diego Region, Pacific Section. SEPM 68:161-178.

West RM (1982) Fossil mammals from the lower Buck Hill Group, Eocene of Trans-Pecos Texas: Marsupicarnivora, primates, Taeniodonta, Condylarthra, bunodont Artiodactyla, and Dinocerata. The Pearce-Sellards Series 35:1-20.

Westgate JW (1988) Biostratigraphic implications of the first Eocene land-mammal fauna from the North American coastal plain. Geology 16:995-998.

Westgate JW (1990) Uintan land mammals (excluding rodents) from an estuarine facies of the Laredo Formation (Middle Eocene, Claiborne Group) of Webb County, Texas. J. Paleontol. 64:454-468.

Wilson JA, and SzalayFS (1976) New adapid primate of European affinities from Texas. Folia Primatol. 25:294-312

Wilson RW (1935) Cricetine-like rodents from the Sespe Eocene of California. Proc. Natl. Acad. Sci. U.S.A. 21:26-32.

Wilson RW (1940a) Californian paramyid rodents. Publ. Carnegie Inst. Wash. 514:59-83.

Wilson RW (1940b) Two new rodents from California. Publ. Carnegie Inst. Wash. 514:85-95.

Wilson RW (1940c) Pareumys remains from the later Eocene of California. Publ. Carnegie Inst. Wash. 514:97-108.

Wolfe JA (1992) Climatic, floristic, and vegetational changes near the Eocene/Oligocene boundary in North America. In DR Prothero and WA Berggren (eds.): Eocene-Oligocene Climatic and Biotic Evolution. Princeton: Princeton University Press, pp. 421-436. 